\title{
Reverse architecting conventional footwear. Towards an A3 Architecture Overview that supports development of alternative footwear architectures.
}

\author{
Winnie Dankers \\ University of Twente \\ University of Twente, P.O.Box 217, 7500AE \\ Enschede, The Netherlands \\ +31(0)534896601 \\ w.dankers@utwente.nl
}

\author{
Gerrit Maarten Bonnema \\ University of Twente \\ University of Twente, P.O.Box 217, 7500AE \\ Enschede, The Netherlands \\ $+31(0) 534892548$ \\ g.m.bonnema@utwente.nl
}

Copyright (C) 2020 by W.Dankers and G.M.Bonnema. Permission granted to INCOSE to publish and use.

\begin{abstract}
The architecture of contemporary footwear is the result of a long history of footwear development. In this history, part of the argumentation behind the architecture has been lost, causing footwear developers to make decisions based on habits and badly underpinned assumptions. New insights on the negative influence of most conventional footwear on human (foot) health and the design freedom that arises from modern manufacturing techniques, create the urge to reconsider the common way of developing. By reverse architecting conventional footwear, this paper derives an A3 Architecture Overview of conventional footwear. In the future this overview should provide a tool for enabling product evolution towards healthy footwear, by allowing developers to consciously and purposefully deviate from 'the standard architecture' while taking into account the consequences of design decisions they make. The approach that is described in this paper is also applicable to the development of architecture overviews for other product families.
\end{abstract}

\section{Background}

In the Western world, footwear is so commonly used that it has become inherently part of our being in the world. It is via footwear that users are in almost constant contact with different types of environments. While serving as an extension of the human body, the earliest footwear seems to merely have had a protective function (Stewart 1972; Swallow 1987). Nowadays, footwear developers have succeeded to include many more functionalities. These functionalities, however, often partly - or even entirely - show a mismatch with the functions of the human body. Footwear developers mistakenly see the foot as an inflexible lever which is fragile and thus needs to be supported and packaged (Robbins \& Hanna 1987). Instead of preserving healthy feet, this can have many adverse shortand long-term effects; the natural shape of the foot can be deformed, loading in the joints can be changed, plantar sensation can be reduced, the foot-strike pattern can be altered, the foot-strength and elastic energy storage can be reduced, evaporation of perspiration can be reduced and the maturation of the foot can be hampered, ultimately resulting in pain, reduced mobility and high societal costs (Buldt \& Menz 2018; D’Août et al. 2009; Frey 2000; Lieberman et al. 2010; Perl, Daoud \& Lieberman 2012; Rose et al. 2011).

Considering those insights, together with the newly obtained design freedom that results from the emergence of modern manufacturing techniques, the common way of developing footwear might unintentionally inhibit footwear developers to use the full potential of knowledge and technology at hand. To support design efforts towards creating product evolutions, first the architecture of present 
footwear has to be documented. Reverse architecting using the so-called A3 Architecture Overview (A3AO) - containing a physical view (showing design decisions), a functional view (providing design argumentation) and a quantification view (providing key-drivers) - can be employed for that purpose (Borches 2010). The aim of this paper is, therefore, to derive an A3AO for footwear development by reverse architecting conventional footwear. In the future, this A3AO should provide a tool for enabling product evolution towards healthy footwear by allowing footwear developers to consciously and purposefully deviate from 'the standard architecture', while constantly allowing them to consider the consequences of the design decisions they make.

\section{Methods}

In reverse architecting, usually three different process phases, being Information Extraction, Abstraction, and Presentation are executed in an iterative manner (Müller, Wong \& Tilley 1995). In reverse architecting conventional footwear, also these three phases are executed. The information extraction phase is executed by analyzing descriptions - that are used by academics as well as in industry - in relation to the parts of non-athletic (men's and women's) footwear as well as athletic footwear. The phase results in an overview of the components of different types of footwear as well as the functions thereof. By comparing the components and functions and by boiling down to the basic elements during the abstraction phase, both a physical description and a functional description is made that is common for most conventional types of footwear. Together with a shortlist of the key-drivers (Bonnema 2008; Heemels et al. 2006) that represent the high-level requirements of specific footwear (quantification view), these provide the views to be presented in an A3 Architecture overview for conventional footwear (presentation phase).

The physical and functional descriptions are evaluated by analyzing a number of random pictures showing footwear anatomy and by iteratively comparing the represented parts / terms with the results until then. The parts and functions that are still lacking can subsequently be included in the final physical and functional view on the A3 Architecture Overview (see Figure 1).

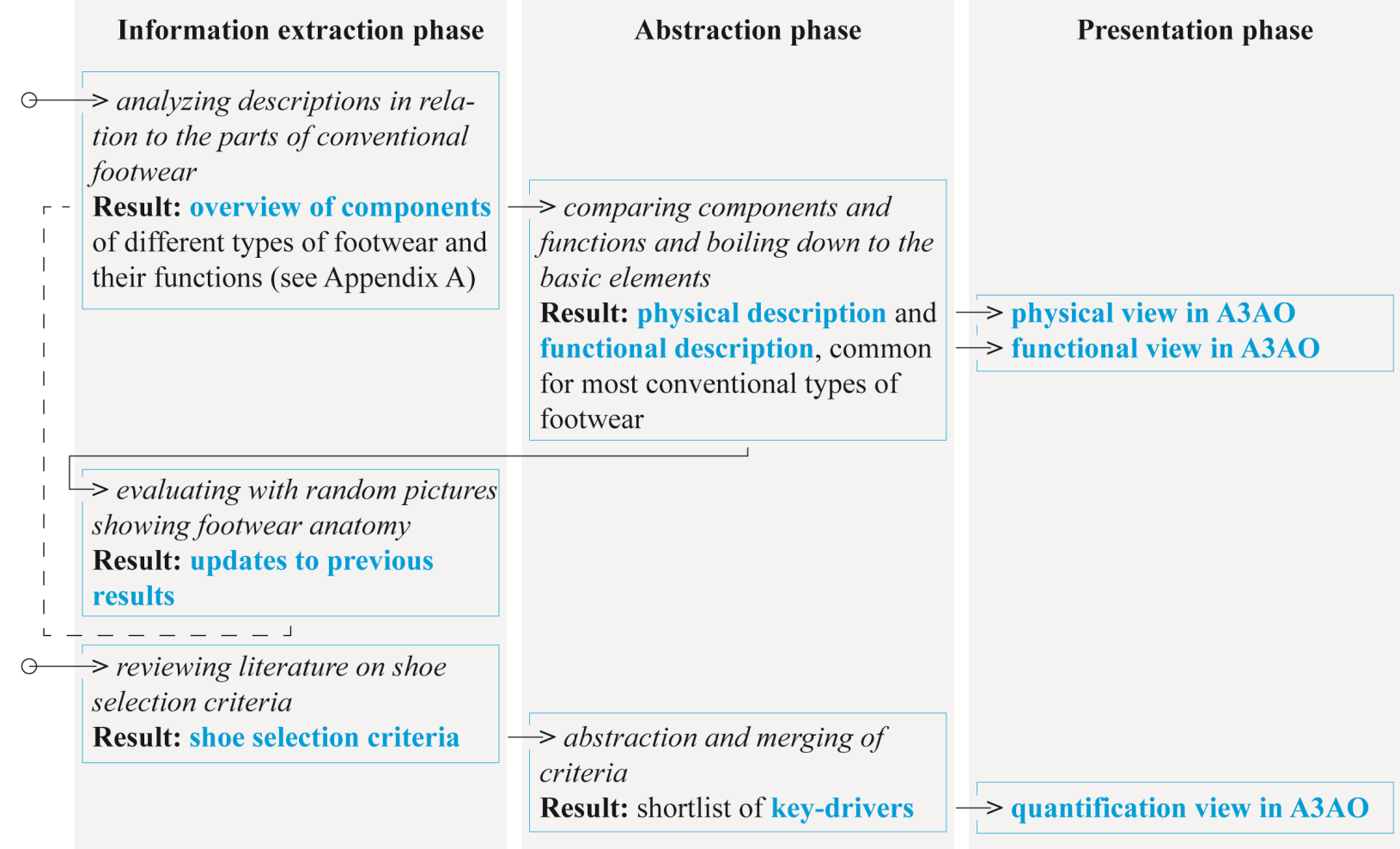

Figure 1. Schematic representation of research flow. 


\section{Physical View}

To create a better understanding of the architecture(s) of conventional footwear, first an overview (table) has been made of the terminology related to the functional parts of conventional footwear (Appendix A). The appendix is organized per sub-assembly of the shoe (shaded rows). The parts of each assembly are organized in individual rows; sub-parts are indented. As conventional footwear comes in many different appearances, dependent on the purposes it is used for, the overview makes a distinction between non-athletic footwear (source columns 1 and 3) and athletic footwear (source columns 2 and 4); those types of footwear show a relatively large difference in the materials, components and manufacturing techniques that are used (McPoil Jr 1988). Where athletic footwear is largely the same for both men and women, non-athletic footwear shows some differences in this respect. These differences, however, mainly concern the geometry of parts that are used. Therefore, the overview does not have to make a specific distinction in this respect.

The sources that have been used to create the overview were selected to vary both in academic (source columns 1 and 2) and industrial (source columns 3 and 4) nature. This was done to investigate whether there is any difference in the use of terminology between the two. The distinction is also visible in the columns of the table. An initial number of resources was selected to start with ((Blazer, Jamrog \& Schnack 2018; Luximon \& Khandual 2018; McPoil Jr 1988; McPoil 2000) that represent the academic viewpoint, and (C\&E_Fashions 2019; Motawi 2015) that represent the industry viewpoint). From the sources, quotations were collected in which terminology related to the functional parts of footwear was used. This terminology was underlined, and the citations were structured based on these terms (rows in table Appendix A). When different terms were considered to address a similar part, these terms are presented in the same row. It is important to note that this does not imply that the terms are full synonyms. In the attempt to complement the overview, a number of additional resources (BootMoodFoot 2019; Davis 2014; Kippen 2009; Kurcina 2017; Muzquiz 2017; Pelizzari 2013; Ramsey et al. 2019; Runner'sWorld 2009; ShoeGuide 2019; Wong \& Luximon 2013) was added.

Eventually, a number of fields in the table (in appendix A) remained empty. These empty fields can be explained by the different architectures of non-athletic and athletic footwear as well as the lacking need for academics to address the terminology related to specific (sub)parts of an assembly.

The terminology was eventually used to create the physical description of conventional (non-athletic and athletic) footwear presented in Figure 2. When multiple terms were mentioned in the same row of the table, a general term was selected to be used for the physical description. An additional description of a non-athletic women's pump was added to show the large overlap in terminology with non-athletic men's footwear while having a complete different appearance; the represented shoe style ('pump') merely consists of fewer parts and has only one term (platform) that is specific for this type of shoe. It should be noted that Figure 2 gives a simplified representation of all parts (and corresponding terminology); for a full overview of all terminology, Appendix A should be referred to.

In each quotation presented in the overview in Appendix A, a possible description of the function of the part at hand was made italic. The italic descriptions of functions were used to derive the functions of conventional footwear in the next section.

\section{Functional View}

To derive the functions that are general for most types of conventional footwear, the terminology from the physical view was used and the italic function descriptions (see Appendix A) were listed together with these terms. In making Table 1, the function descriptions were rephrased by using terms from the 'Functional basis reconciled function set' defined by the National Institute of Standards and Technology, NIST (Hirtz et al. 2002). This was done with the aim to boil down to a limited and uncluttered set of different functions per part, that adheres to accepted terminology. 

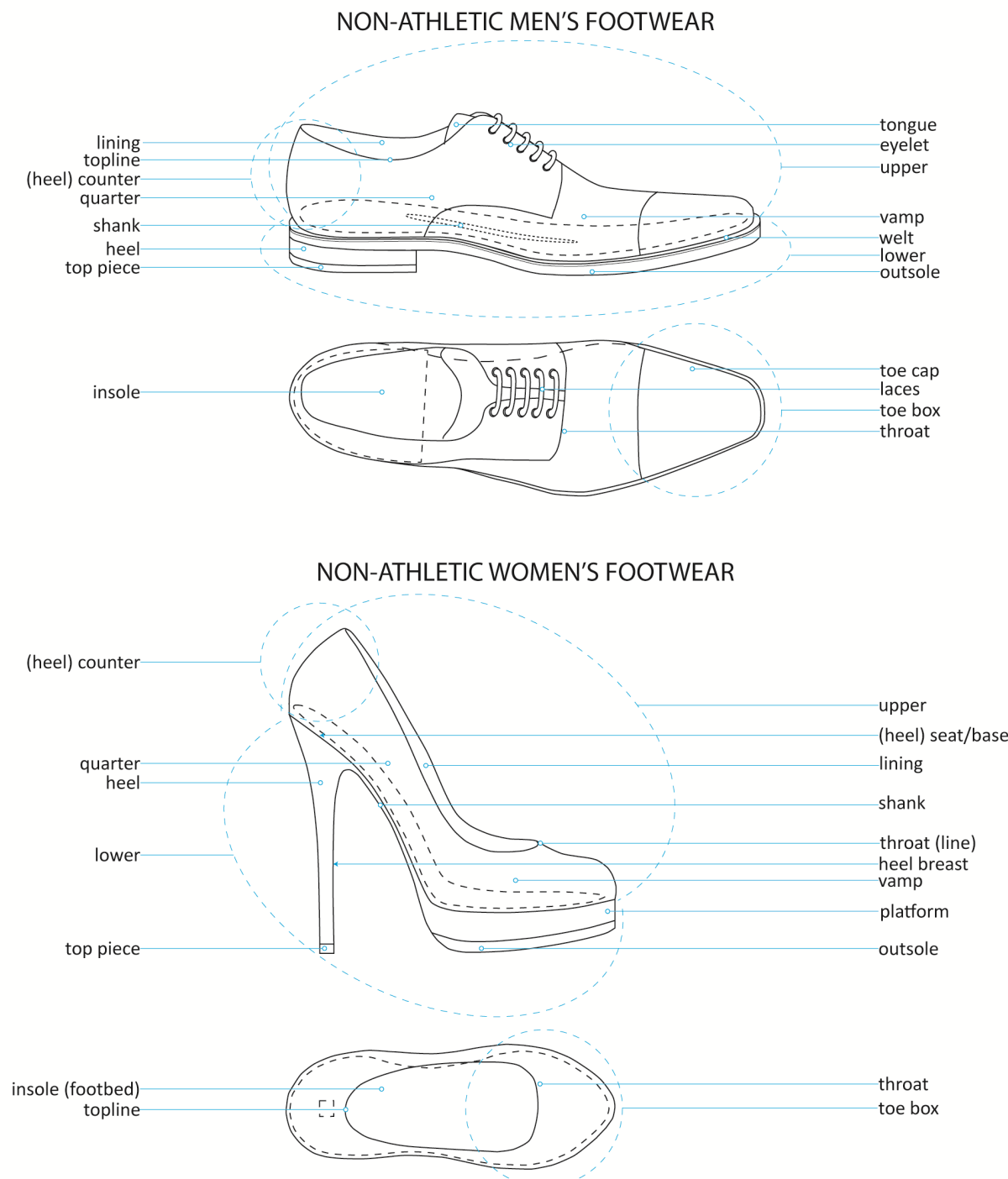

ATHLETIC FOOTWEAR
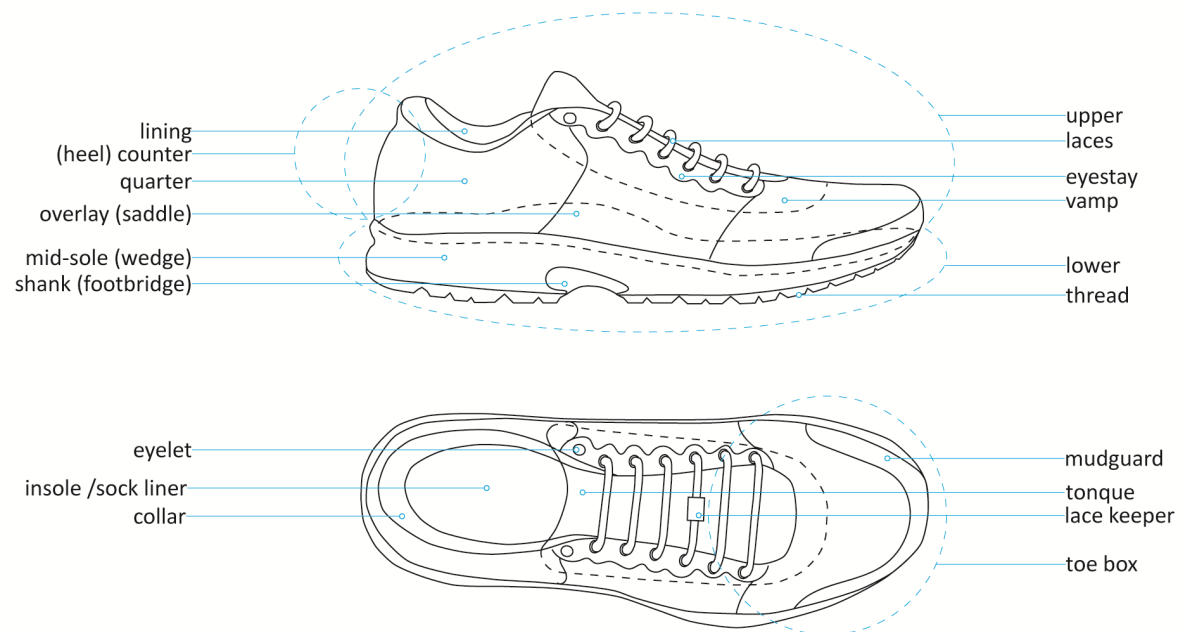

Figure 2. Physical View: Men's and women's non-athletic and athletic footwear 
Table 1: Derived functions of conventional footwear

\begin{tabular}{|c|c|}
\hline Component & Function(s) \\
\hline \multicolumn{2}{|r|}{ Upper } \\
\hline Upper & 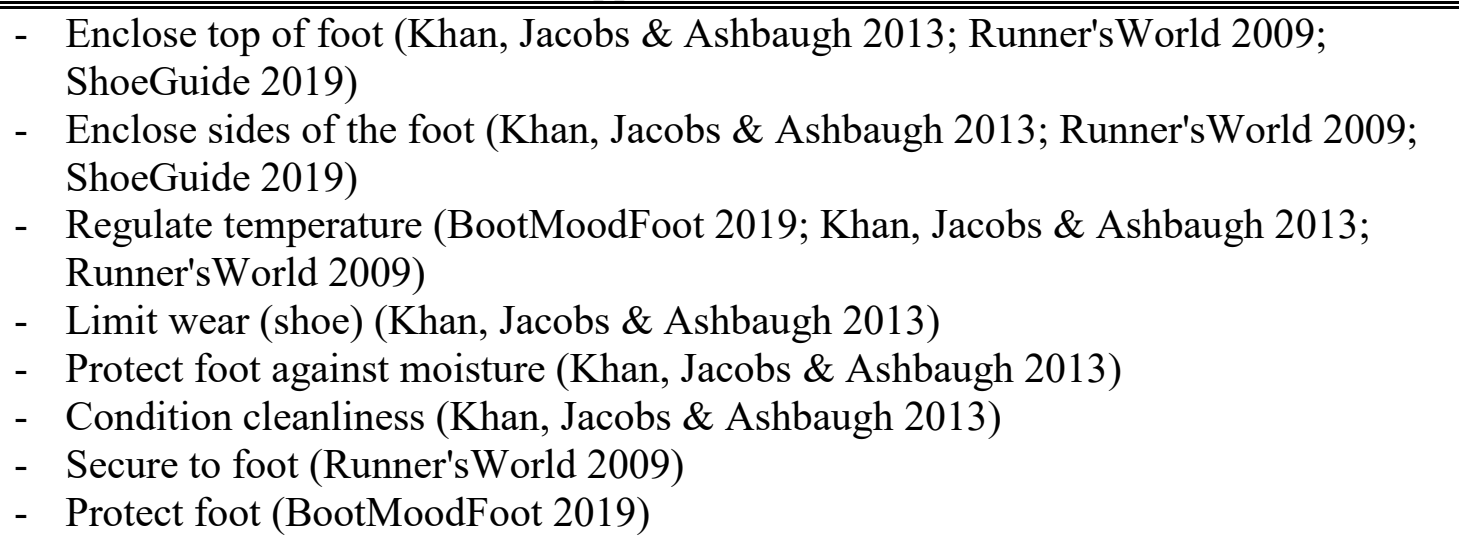 \\
\hline Vamp & $\begin{array}{ll}\text { - } & \text { Enclose forefoot (McPoil Jr 1988) } \\
\text { - } & \text { Feel comfortable (to the skin) (McPoil Jr 1988) } \\
\text { - } & \text { Limit wear (shoe) (BootMoodFoot 2019) } \\
\text { - } & \text { Regulate /maintain temperature (Motawi 2015) }\end{array}$ \\
\hline $\begin{array}{l}\text { Toe-box/ } \\
\text { toe cap }\end{array}$ & $\begin{array}{l}\text { - Maintain shape (shoe) (Blazer, Jamrog \& Schnack 2018; Luximon \& Khandual } \\
\text { 2018) } \\
\text { - } \text { Enclose toes (McPoil Jr 1988) } \\
\text { - } \text { Display personality (McPoil Jr 1988; Motawi 2015) } \\
\text { - } \quad \text { Protect the foot (ShoeGuide 2019) } \\
\text { - } \quad \text { Limit wear (shoe) (Muzquiz 2017; ShoeGuide 2019) }\end{array}$ \\
\hline Mudguard & - Limit wear (shoe) (Kurcina 2017) \\
\hline Throat line & $\begin{array}{l}\text { - Secure to the foot / Detach from the foot (Kippen 2009) } \\
\text { - Guide foot into shoe (Kippen 2009) }\end{array}$ \\
\hline Tongue & $\begin{array}{l}\text { - Distribute pressure (Khan, Jacobs \& Ashbaugh 2013; Motawi 2015; Muzquiz 2017) } \\
\text { - } \quad \text { Limit dirt entry (BootMoodFoot 2019) }\end{array}$ \\
\hline Eye-stay & - Locate eyelets/webbings for lacing (shoe) (Motawi 2015) \\
\hline Laces & $\begin{array}{l}\text { - Secure to the foot / Detach from the foot (BootMoodFoot 2019; McPoil 2000) } \\
\text { - } \text { Adjust fit (shoe) (BootMoodFoot 2019) }\end{array}$ \\
\hline $\begin{array}{l}\text { Quarter/ } \\
\text { shaft }\end{array}$ & $\begin{array}{ll}- & \text { Enclose back of the foot (BootMoodFoot 2019) } \\
- & \text { Enclose ankles, calf, and leg (BootMoodFoot 2019) }\end{array}$ \\
\hline $\begin{array}{l}\text { Overlay/ } \\
\text { saddle }\end{array}$ & $\begin{array}{l}\text { - } \text { Maintain shape (shoe) (Runner's World 2009) } \\
\text { - } \text { Secure midfoot (Runner'sWorld 2009) } \\
\text { - } \quad \text { Support arch (Runner'sWorld 2009) }\end{array}$ \\
\hline $\begin{array}{l}\text { Heel } \\
\text { counter }\end{array}$ & $\begin{array}{l}\text { - } \text { Stabilize hindfoot / secure heel (Blazer, Jamrog \& Schnack 2018; McPoil Jr 1988) } \\
\text { - } \text { Maintain shape (shoe) (BootMoodFoot 2019; Luximon \& Khandual 2018; } \\
\text { ShoeGuide 2019) } \\
\text { - } \quad \text { Stabilize foot (Muzquiz 2017) } \\
\text { - } \quad \text { Constrain motion (Kippen 2009) }\end{array}$ \\
\hline $\begin{array}{l}\text { Topline/ } \\
\text { collar }\end{array}$ & $\begin{array}{l}\text { - Limit dirt entry (McPoil Jr 1988; Runner'sWorld 2009) } \\
\text { - } \quad \text { Feel comfortable (to the skin) (Khan, Jacobs \& Ashbaugh 2013) }\end{array}$ \\
\hline Eyelets & Guide laces (shoe) (Muzquiz 2017) \\
\hline Linings & $\begin{array}{l}\text { - Feel comfortable (to the skin) (Kippen 2009; ShoeGuide 2019) } \\
\text { - } \quad \text { Limit wear (shoe) (Kippen 2009; ShoeGuide 2019) }\end{array}$ \\
\hline $\begin{array}{l}\text { Welt/ } \\
\text { feather }\end{array}$ & - Join parts (shoe) (BootMoodFoot 2019; Muzquiz 2017; ShoeGuide 2019) \\
\hline
\end{tabular}




\begin{tabular}{|c|c|}
\hline Component & Function(s) \\
\hline \multicolumn{2}{|r|}{ Lower } \\
\hline Outsole & $\begin{array}{ll}\text { - } & \text { Protect foot (McPoil Jr 1988) } \\
\text { - } & \text { Protect foot against frictional forces (Blazer, Jamrog \& Schnack 2018) } \\
\text { - } & \text { Protect foot against moisture (Kippen 2009) } \\
\text { - } & \text { Transmit force (Blazer, Jamrog \& Schnack 2018; Khan, Jacobs \& Ashbaugh 2013; } \\
& \text { Kippen 2009; Motawi 2015) } \\
\text { - } & \text { Reduce shocks (Khan, Jacobs \& Ashbaugh 2013; Runner's World 2009) } \\
\text { - } & \text { Support foot (Runner'sWorld 2009) } \\
\text { - } & \text { Limit wear (shoe) (Khan, Jacobs \& Ashbaugh 2013; Kippen 2009) } \\
\text { - } & \text { Limit torsion (shoe) (Khan, Jacobs \& Ashbaugh 2013) } \\
\text { - } & \text { Allow flexion (shoe) (Khan, Jacobs \& Ashbaugh 2013) }\end{array}$ \\
\hline Tread & $\begin{array}{ll}\text { - } & \text { Transmit force (McPoil Jr 1988; Runner'sWorld 2009) } \\
\text { - } & \text { Reduce shocks (McPoil Jr 1988; Runner'sWorld 2009) }\end{array}$ \\
\hline Midsole & $\begin{array}{ll}\text { - } & \text { Protect foot (Davis 2014) } \\
\text { - } & \text { Reduce shocks (C\&E_Fashions 2019; Davis 2014; Khan, Jacobs \& Ashbaugh } \\
& \text { 2013; Motawi 2015) } \\
\text { - } & \text { Stabilize foot (Khan, Jacobs \& Ashbaugh 2013) } \\
\text { - } & \text { Enclose foot (Motawi 2015) } \\
\text { - } & \text { Feel comfortable (Motawi 2015) } \\
\text { - } & \text { Support foot (Motawi 2015) }\end{array}$ \\
\hline $\begin{array}{l}\text { Midsole } \\
\text { wedge }\end{array}$ & $\begin{array}{l}\text { - } \text { Increase angle (Khan, Jacobs \& Ashbaugh 2013; Wong \& Luximon 2013) } \\
\text { - } \quad \text { Reduce shocks (Khan, Jacobs \& Ashbaugh 2013; McPoil Jr 1988) } \\
\text { - } \quad \text { Stabilize foot (Khan, Jacobs \& Ashbaugh 2013; McPoil Jr 1988) }\end{array}$ \\
\hline $\begin{array}{l}\text { Insole } \\
\text { (board)/ } \\
\text { foodbed }\end{array}$ & $\begin{array}{ll}\text { - } & \text { Provide template (shoe-fitting) (Blazer, Jamrog \& Schnack 2018) } \\
\text { - } & \text { Maintain shape (shoe) (Motawi 2015) } \\
\text { - } & \text { Reduce shocks (Motawi 2015) }\end{array}$ \\
\hline $\begin{array}{l}\text { Shank/ } \\
\text { footbridge }\end{array}$ & $\begin{array}{ll}\text { - } & \text { Limit torsion (shoe) (McPoil Jr 1988; Runner'sWorld 2009) } \\
\text { - } & \text { Control flexion (shoe) (McPoil Jr 1988; Runner'sWorld 2009) } \\
\text { - } & \text { Limit flexion zone (shoe) (McPoil Jr 1988) } \\
\text { - } & \text { Stabilize foot (Ramsey et al. 2019) } \\
\text { - } & \text { Limit wear (shoe) (C\&E_Fashions 2019) } \\
\text { - } & \text { Support foot (C\&E_Fashions 2019; Runner'sWorld 2009) } \\
\text { - } & \text { Constrain motion (Kippen 2009) }\end{array}$ \\
\hline Heel & $\begin{array}{ll}\text { - } & \text { Display personality (McPoil Jr 1988) } \\
\text { - } & \text { Reduce shocks (C\&E_Fashions 2019) } \\
\text { - } & \text { Increase height / provide heel lift (ShoeGuide 2019) } \\
\end{array}$ \\
\hline Top piece & - $\quad$ Limit wear (shoe) (Muzquiz 2017) \\
\hline Heel seat & - Enclose heel (upper shoe) (ShoeGuide 2019) \\
\hline Platform & - $\quad$ Increase height (Wong \& Luximon 2013) \\
\hline \multicolumn{2}{|r|}{ Assembly } \\
\hline $\begin{array}{l}\text { Stitching/ } \\
\text { glue/l } \\
\text { nails }\end{array}$ & - Join parts (shoe) (see Evaluation section) \\
\hline
\end{tabular}


Eventually a general list of possible footwear functions was derived by combining the functions from Table 1 and by removing the duplicates (see Table 2).

Table 2: Functional View: Functions of conventional footwear

Functions of conventional footwear

- Secure to foot (secure mid foot, secure heel, ...) - Adjust fit (shoe)

- Detach from the foot

- Maintain shape (shoe)

- Protect foot/body (frictional forces, moisture,...) - Support foot (arch, ...)

- Enclose foot (optional: ankles, calf and leg) - Stabilize foot/body

- Guide foot into shoe

- Constrain motion

- Transmit force (foot to ground)

- Reduce shocks

- Regulate temperature (foot)

- Increase height

- Display personality

- Increase angle

- Distribute pressure

- Limit torsion (shoe)

- Limit dirt entry

- Control flexion / limit flexion zone (shoe)

- Feel comfortable (to the skin) (shoe)

- Locate eyelets / webbings for lacing (shoe)

- Limit wear (shoe)

- Guide laces (shoe)

- Condition cleanliness (shoe)

- Join parts (shoe)

- Provide template (shoe-fitting)

\section{Quantification View}

To define the quantification view, again the three reverse architecting phases were executed (Müller, Wong \& Tilley 1995). As the quantification view was not really focused on in this phase of the research, this was done in a quick manner. First, information was extracted by reviewing literature on shoe selection criteria (Enke, Laskowski \& Thomsen 2009; Goonetilleke \& Luximon 2001; Miller 1976). The following shoe-selection criteria were mentioned: Arch type, Shoe design, Color, Appearance, Cost, Brand, Comfort, Fit (Enke, Laskowski \& Thomsen 2009); Fashion, Price, Comfort, Fit, Performance, Durability (Miller 1976); Size, Shape, Flexibility, Style, Weight, Inside shoe climate, Materials, Tread, Cushioning (Goonetilleke \& Luximon 2001). It is interesting that 'healthfulness' is not mentioned by these sources as a selection criteria. Recent insights into the negative influence of most conventional footwear on human (foot) health (Buldt \& Menz 2018; D'Août et al. 2009; Frey 2000; Lieberman et al. 2010; Perl, Daoud \& Lieberman 2012; Rose et al. 2011), however, might cause healthfulness to become a key-driver. Therefore, this term was also included in the overall list. 
Abstraction and merging of the criteria eventually lead to the following shortlist of key-drivers that, for now, establish the quantification view:

- $\quad$ Price

- $\quad$ Comfort

- Appearance

- Durability

- $\quad$ Performance

- Healthfulness

Together, these key-drivers represent the interests of the end user. We need to expand and update the set to also include interests of other stakeholders, like the producer and store operator.

\section{Evaluation}

To evaluate both the physical and functional overviews that were established, first a number of pictures of footwear anatomy was randomly collected via Pinterest (see Figure 3) and the used terminology was compared with the overviews in Appendix A and Figure 3.

The comparison lead to the following list of parts that were not yet described:

- Toe burst panel; A part that is used to reduce wear to the upper caused by the toes/nails. The function of the toe burst panel can also be fulfilled by the toe-box/toe cap or mudguard.

- $\quad$ Mustache; A part with a mustache shaped pattern, added on the outside of the quarter, at the back, above the counter. The function of the mustache is similar to that of the counter and is used in classic sneakers.

- Lace-tip: The strengthened tip(s) of the laces. The tips allowing for easy pushing/pulling the laces through the eyelets.

- $\quad$ Bumper: The rubber strip attached to the forward facing part of a sneaker sole. The function is to decrease wear to the front of the sole.

- $\quad$ Foxing: The term foxing is used for almost any additional piece of leather/fabric attached to the outside of the vamp/quarter to add additional strength or to reduce wear, similar to an 'overlay'.

- $\quad$ Back-strap/rear-strap: The loop that is attached to the back of the quarter, sometimes as an extension of the back-stay. It can be used for easy shoe-access and prevents the back of the quarter from being suppressed.

- Back-tab: A different word for Achilles tendon protector.

- $\quad$ Air (or gel) Unit: An air (or gel) chamber added to the midsole for additional suspension.

- Insertor support / support insert: An insert in the midsole for additional support / to constrain motion.

- $\quad$ Rearfoot stabilizer: a support insert in the heel part of the midsole, to stabilize the rearfoot.

- $\quad$ Stitching / glue / nails: The materials used to assemble all different parts together. 


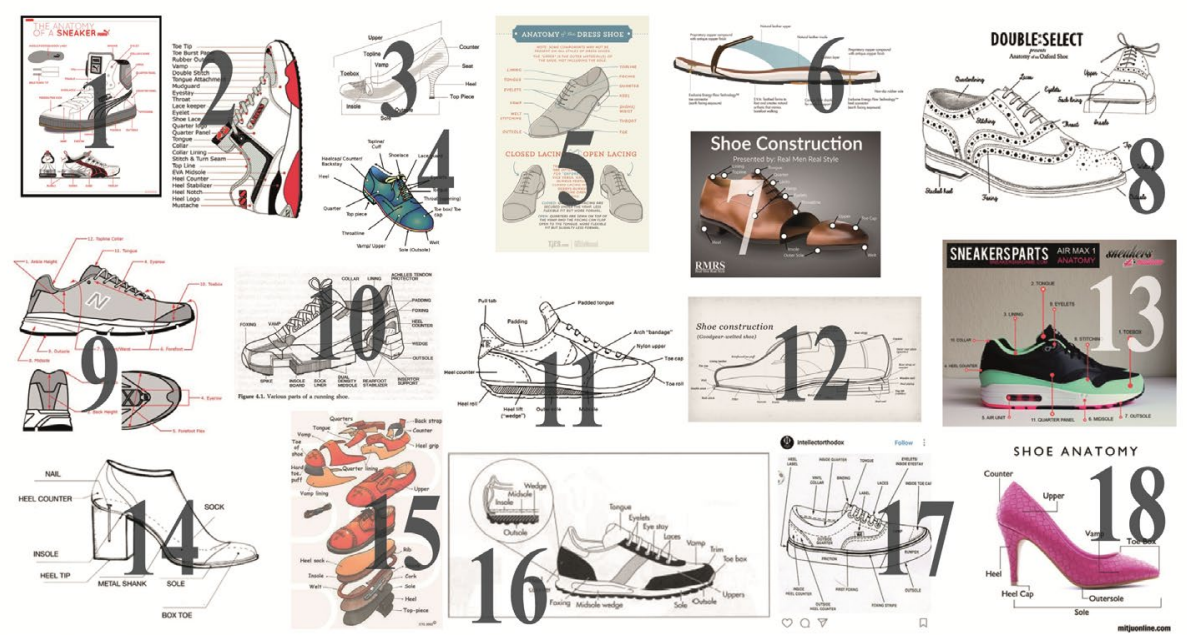

Figure 3. Overview of images showing footwear anatomy.

(Derived from https://pin.it $/<x y z>$; where $<$ xyz $>$ : 1=5qovk6xb12m7qp 2=anfqgxi33logo3 3=44dusbaomfskds

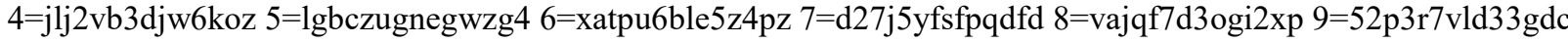

$10=$ yyftiqax7xkrt3 11=qw5bopej4g56lv 12=464zdma6ypjd6g 13=st3kosjnw4z2fj 14=mdzmihqoul $7 \mathrm{~d} 2 \mathrm{y}$ $15=$ ia4bjqqrk $5 \mathrm{r} 7 \mathrm{mj}$ 16=smajvqdjdoe $5 \mathrm{ak} 17=$ =r4neknitv4u3gm 18=cy6kgwakte2qmr)

As most of the parts are used in relation to specific types of footwear only, the terms were added to Appendix A (dashed underline), but like in the first iteration without including them in the physical view (Figure 2) and functional view (Table 2 ) respectively. The materials used to assemble all different footwear parts together like glue, nails, stitching, however, are essential for any type of shoe. Therefore, these were added to table $1 \& 2$ and the final presentation in Figure 4 (A3AO overview side) and Figure 5 (A3AO summary side) (for the full size version, see Appendix B: The A3AO of Conventional Footwear).

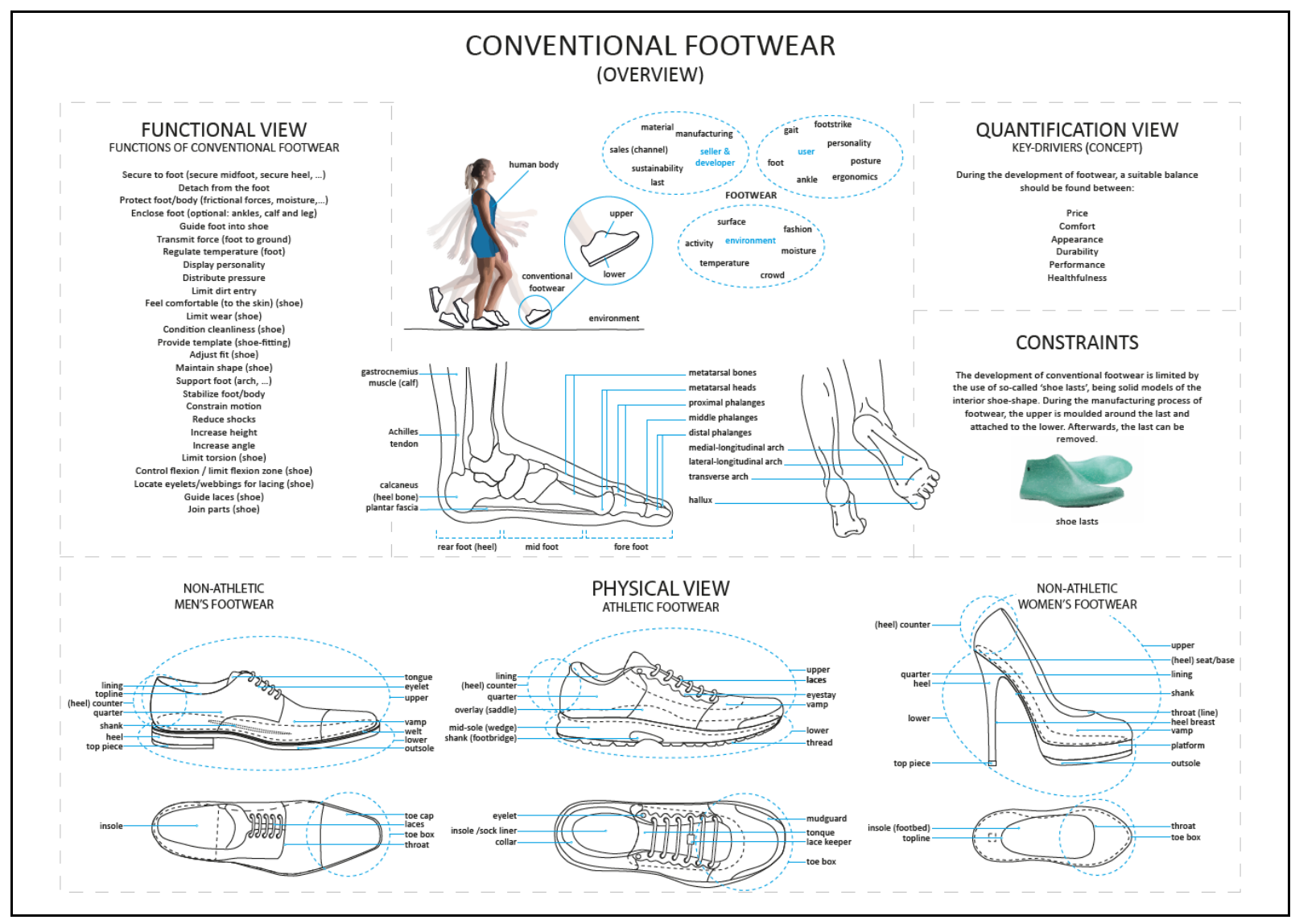

Figure 4: A3AO of Conventional Footwear; Overview 


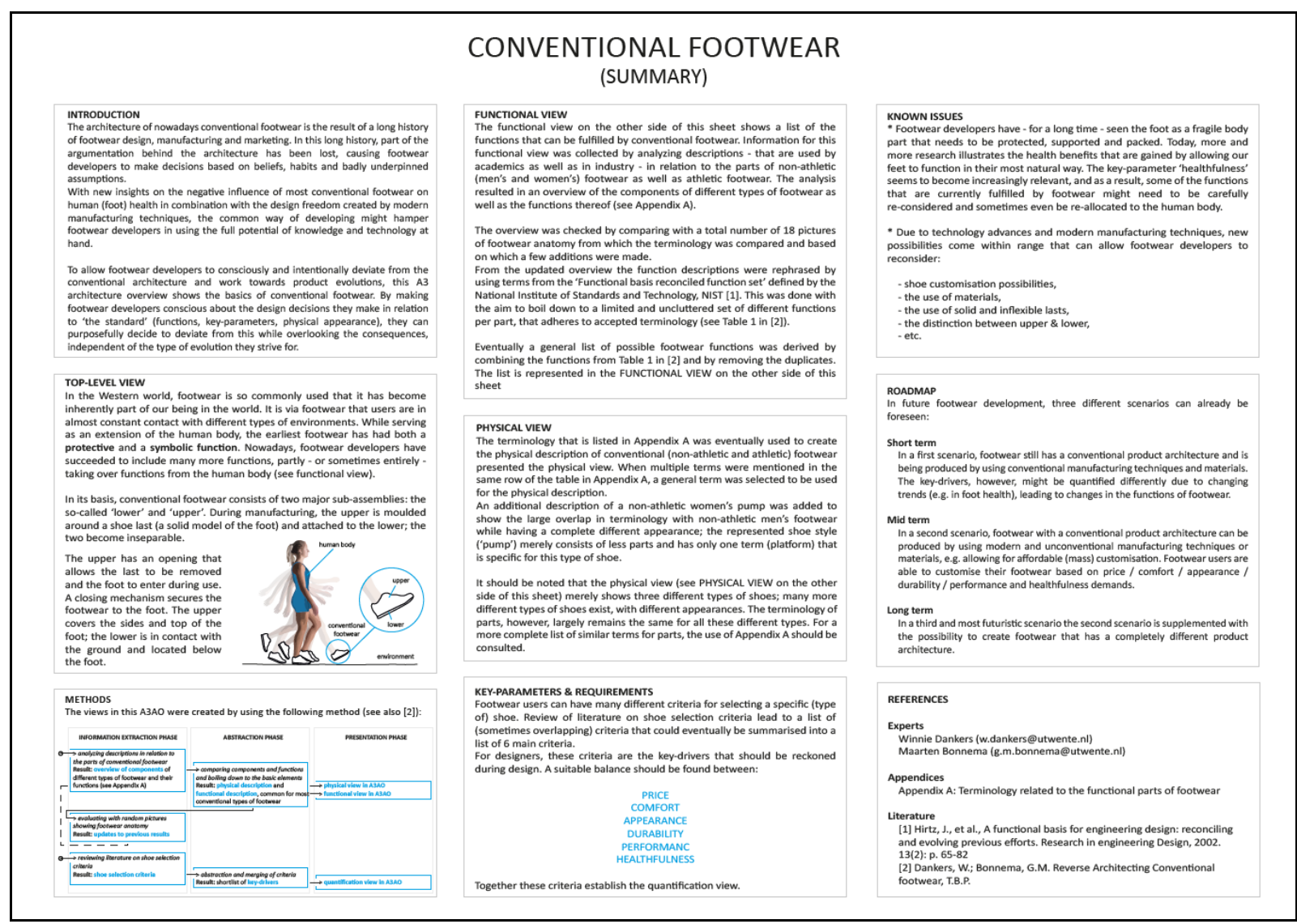

Figure 5: A3AO of Conventional Footwear; Summary

\section{Conclusions}

The established A3 Architecture overview shows the result of the decomposition of conventional footwear in relevant architectural aspects. These aspects form a solid basis to enable future footwear development and support the well thought-through development of new architectures. The overviews provide stakeholders of footwear development with means to easily discuss alternative requirements and/or key-parameters, alternative trade-offs, and to enable them to anticipate the impact thereof. In particular the so far undervalued healthiness of footwear can be improved using this architecture description, without compromising existing requirements.

\section{Future work}

The A3AO of Conventional Footwear can only prove its success when it is being used by footwear developers and has the desired results. As the $\mathrm{A} 3 \mathrm{AO}$ is developed in the context of a bigger project on tools and guidelines for the development of healthy footwear, this will be the first area of application. In relation to this project, it will be complemented with technical knowledge on e.g. materials and production techniques and in-depth understanding of different stakeholder needs (shoe users, producers, shops, etc.). The use, however, is not limited to this project. It is well imaginable that it can also form a good basis for evolutionary developments in e.g. safety shoes. Moreover, the approach that was used in this paper can be applied to develop architecture overviews for other product families as well.

\section{References}

Blazer, MM, Jamrog, LB \& Schnack, LL 2018, 'Does the Shoe Fit? Considerations for Proper Shoe Fitting', Orthopaedic Nursing, vol. 37, no. 3, pp. 169-174. 
Bonnema, GM 2008, 'Funkey architecting: an integrated approach to system architecting using functions, key drivers and system budgets',

BootMoodFoot 2019, What are the parts of a shoe and a sneaker? An anatomy of a shoe., viewed 07-29-2019, <https://bootmoodfoot.com/parts-anatomy-of-a-shoe/>.

Borches, D 2010, A3 architecture overviews: a tool for effective communication in product evolution, thesis, $\mathrm{PhD}$ thesis University of Twente.

Buldt, AK \& Menz, HB 2018, 'Incorrectly fitted footwear, foot pain and foot disorders: a systematic search and narrative review of the literature', Journal of Foot and Ankle Research, vol. 11, no. 1, 2018/07/28, p. 43.

C\&E_Fashions 2019, Glossary of Shoe Terms, viewed 07-25-2019, $<$ https://www.candefashions.com>.

D'Août, K, Pataky, TC, De Clercq, D \& Aerts, P 2009, 'The effects of habitual footwear use: foot shape and function in native barefoot walkers', Footwear Science, vol. 1, no. 2, 2009/06/01, pp. 81-94.

Davis, IS 2014, 'The Re-emergence of the Minimal Running Shoe', Journal of Orthopaedic \& Sports Physical Therapy, vol. 44, no. 10, pp. 775-784.

Enke, RC, Laskowski, ER \& Thomsen, KM 2009, 'Running Shoe Selection Criteria Among Adolescent Cross-Country Runners', $P M \& R$, vol. 1, no. 9, 2009/09/01/, pp. 816-819.

Frey, C 2000, 'Foot Health and Shoewear for Women', Clinical Orthopaedics and Related Research (1976-2007), vol. 372, pp. 32-44.

Goonetilleke, RS \& Luximon, A 2001, 'Designing for comfort: a footwear application,' Proceedings of the computer-aided ergonomics and safety conference,

Heemels, W, Somers, L, van den Bosch, P, Yuan, Z, van der Wijst, B, van den Brand, A \& Muller, G 2006, 'The key driver method', Boderc: Model-Based Design of High-Tech Systems, edited by W. Heemels and GJ Muller, pp. 27-42.

Hirtz, J, Stone, RB, McAdams, DA, Szykman, S \& Wood, KL 2002, 'A functional basis for engineering design: reconciling and evolving previous efforts', Research in engineering Design, vol. 13, no. 2, pp. 65-82.

Khan, MN, Jacobs, BC \& Ashbaugh, S 2013, 'Considerations in Footwear and Orthotics', Primary Care: Clinics in Office Practice, vol. 40, no. 4, 2013/12/01/, pp. 1001-1012.

Kippen, C 2009, The anatomy of the shoe, viewed 07-23-2019, $<\underline{\text { http://allaboutshoes-toeslayer.blogspot.com/2009/10/anatomy-of-shoe-according-to-mcph }}$ oil.html>.

Kurcina, M 2017, Anatomy of a shoe, viewed 07-27-2019, $<$ https://spotterup.com/anatomy-of-a-shoe/>.

Lieberman, DE, Venkadesan, M, Werbel, WA, Daoud, AI, D’andrea, S, Davis, IS, Mang'Eni, RO \& Pitsiladis, Y 2010, 'Foot strike patterns and collision forces in habitually barefoot versus shod runners', Nature, vol. 463, no. 7280, p. 531.

Luximon, A \& Khandual, A 2018, '18 - Footwear', in J Williams (ed.) Waterproof and Water Repellent Textiles and Clothing, Woodhead Publishing, pp. 533-558.

McPoil Jr, TG 1988, 'Footwear', Physical therapy, vol. 68, no. 12, pp. 1857-1865.

McPoil, TG 2000, 'Athletic footwear: Design, performance and selection issues', Journal of Science and Medicine in Sport, vol. 3, no. 3, 2000/09/01/, pp. 260-267.

Miller, R 1976, Manual of shoemaking, C. \& J. Clark Ltd.

Motawi, W 2015, Shoe Dictionary, viewed 07-25-2019, <https://sneakerfactory.net>.

Müller, HA, Wong, K \& Tilley, SR 1995, 'Understanding software systems using reverse engineering technology', in Object-Oriented Technology for Database and Software Systems, World Scientific, pp. 240-252.

Muzquiz, A 2017, Shoe Anatomy 101 - Vamp, Welt, Quarter and More, viewed 07-29-2019, $<\underline{\text { https://www.heddels.com/2017/09/shoe-anatomy-101-vamp-welt-quarter-and-more/>. }}$.

Pelizzari, O 2013, '6 - Shoe design development', in A Luximon (ed.) Handbook of Footwear Design and Manufacture, Woodhead Publishing, pp. 117-127. 
Perl, DP, Daoud, AI \& Lieberman, DE 2012, 'Effects of footwear and strike type on running economy', Med Sci Sports Exerc, vol. 44, no. 7, pp. 1335-43.

Ramsey, CA, Lamb, P, Kaur, M, Baxter, GD \& Ribeiro, DC 2019, "“How are running shoes assessed? A systematic review of characteristics and measurement tools used to describe running footwear"', Journal of Sports Sciences, pp. 1-13.

Robbins, SE \& Hanna, AM 1987, 'Running-related injury prevention through barefoot adaptations', Med Sci Sports Exerc, vol. 19, no. 2, pp. 148-156.

Rose, W, Bowser, B, McGrath, R, Salerno, J, Wallace, J \& Davis, I 2011, 'Effect of Footwear on Balance,' American Society of Biomechanics Annual Meeting,

Runner'sWorld 2009, Shoepaedia: Key Running Shoe Terms Explained, viewed 07-23-2019, $<$ https://www.runnersworld.com/uk $>$.

ShoeGuide 2019, Anatomy of the Shoe, viewed 07-29-2019, $<$ https://www.shoeguide.org/shoe anatomy/>.

Stewart, SF 1972, 'Footgear - its history, uses and abuses', Clin Orthop Relat Res, vol. 88, pp. 119-130.

Swallow, A 1987, 'The history of shoes', Bailliere's clinical rheumatology, vol. 1, no. 2, pp. 413-429. Wong, WC \& Luximon, A 2013, '8 - Footwear drawing templates and shoe design', in A Luximon (ed.) Handbook of Footwear Design and Manufacture, Woodhead Publishing, pp. 150-174.

\section{Biography}

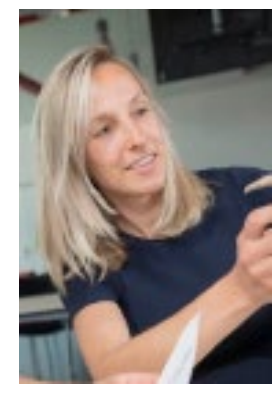

Winnie Dankers received her Master's degree in Industrial Design Engineering from the University of Twente (2009) and continued working as an assistant professor at the Laboratory of Design, Production and Management of the faculty of Engineering Technology. She gained teaching experience in IDE in general, scientific \& technical writing and visual communication and her research focused on Information Management. After becoming a mother and shortly focusing on lecturing only, she developed an interest in the field of footwear development. She now researches how footwear developers can be supported in developing footwear that better matches the natural functions of the body.

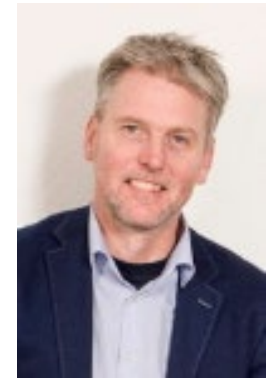

(Gerrit) Maarten Bonnema is an associate professor in systems engineering and multidisciplinary design at the Department of Design, Production and Management of the Faculty of Engineering Technology at the University of Twente. He has worked as a Systems Engineer at ASML. His research aims at supporting system designers, conceptual design and mechatronic design by improving multidisciplinary communication, and systems thinking. An overview of publications can be found at http://www.tinyurl.com/MaBoPubs. Two main application areas are high-tech systems and electric mobility. He has a broad teaching expertise spanning design in general, industrial design, and systems engineering. 
TERMINOLOGY RELATED TO THE FUNCTIONAL PARTS OF FOOTWEAR

Note: The terms that have a dashed underline are added after evaluation of the table.

\begin{tabular}{|c|c|c|c|c|c|}
\hline \multirow{2}{*}{\multicolumn{2}{|c|}{ Terminology }} & \multicolumn{4}{|r|}{ C } \\
\hline & & \multirow{3}{*}{$\begin{array}{l}\text {-"The components of a shoo can be grouped broadly into } \\
\text { those parts that make up the upper and those parts that } \\
\text { constitute the lower or bottom."(McPoil II 1988) } \\
\text {-"Materials that can be used for shoe uppers can also be } \\
\text { used in shoe soles..."(Luximon \& Khandual 2018) } \\
\text { "The outsole is the protective } \\
\text { layer of material between the plantar } \\
\text { surface of the foot and the ground."(McPoil Jr 1988) }\end{array}$} & Academic \& Athletic & Industry \& Non-Athletic & \multirow{3}{*}{ 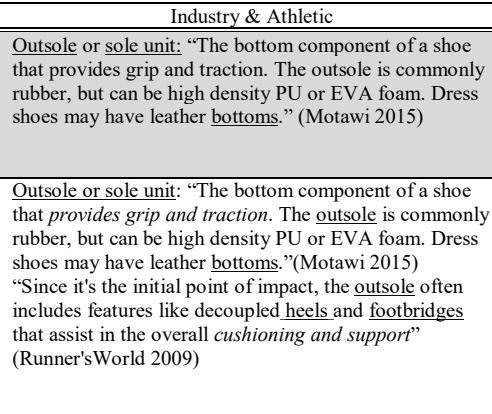 } \\
\hline \multicolumn{2}{|c|}{$\begin{array}{l}\begin{array}{l}\text { lower/ bottom/ sole unit// } \\
\text { sole/soles }\end{array} \\
\end{array}$} & & \multirow{2}{*}{ 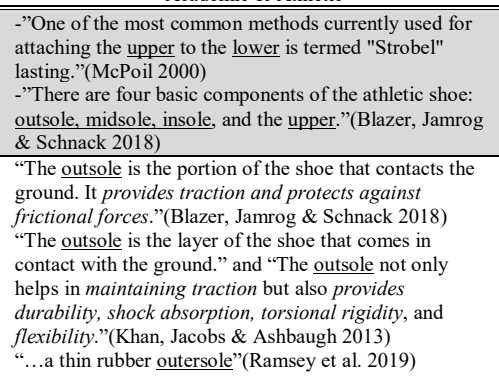 } & \multirow{2}{*}{ 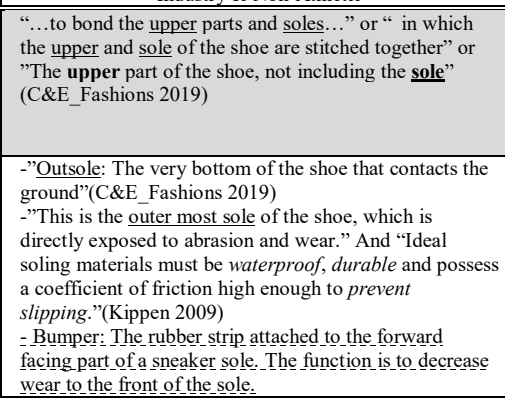 } & \\
\hline $\begin{array}{l}\text { outsole/ } \\
\text { outersole / } \\
\text { bumperer }\end{array}$ & & & & & \\
\hline & $\begin{array}{l}\text { tread } \\
\text { (waffles/ } \\
\text { lugs/nubs/r } \\
\text { ipples) }\end{array}$ & & $\begin{array}{l}\text { "Nubs, ripples, and waffles are commonly placed on the } \\
\text { outsoles of running shoes. The original reason for this } \\
\text { type of outsole design was to improve traction during } \\
\text { cross-country running. It has been shown that the waffle } \\
\text { or nubbed outsole will contribute to shock attenuation } \\
\text { while running on asphalt and concrete."(McPoil Jr 1988) }\end{array}$ & & 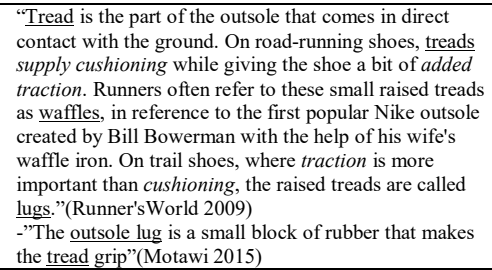 \\
\hline midsole & & & 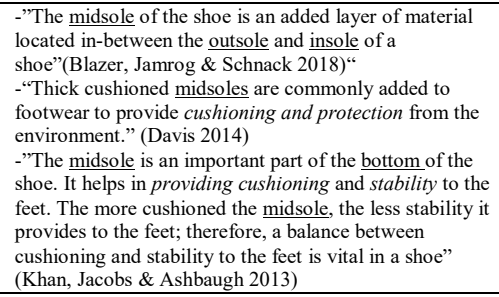 & $\begin{array}{l}\text {-"Midsole: The part of the shoe between the outsole and } \\
\text { where the foot rests, usually cushioned." (C\&E_Fashions } \\
\text { 2019) }\end{array}$ & $\begin{array}{l}\text { "Midsole: The component of a shoe between the upper } \\
\text { and outsole used to provide cushioning, fit, comfort and } \\
\text { support."(Motawi 2015) }\end{array}$ \\
\hline $\begin{array}{l}\text { midsole } \\
\text { wedge/ } \\
\text { wedge/ } \\
\text { medial } \\
\text { post/ } \\
\text { air (or gel }) \\
\text { unit. }\end{array}$ & & $\begin{array}{l}\text { "In } 85 \mathrm{~mm} \text { heel design, some designers will add a wedge } \\
\text { or front platform to increase the height. However, the } \\
\text { height of the insole should be kept to } 85 \mathrm{~mm} \text { m. In drawing } \\
\text { shoes with a front platform, the heel must be extended } \\
\text { and elongated to the same height as the front } \\
\text { plattorm."(Wong \& Luximon 2013) }\end{array}$ & 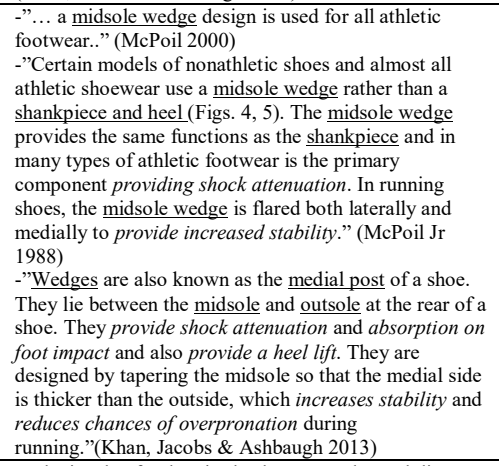 & & 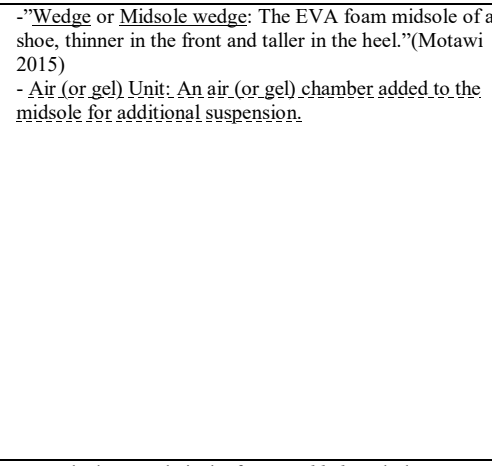 \\
\hline $\begin{array}{l}\text { insole } \\
\text { (board)/ } \\
\text { foodbed/ } \\
\text { insock/ } \\
\text { sock liner/ } \\
\text { sockliner } \\
\text { foodbed/ } \\
\text { lasting } \\
\text { board }\end{array}$ & & $\begin{array}{l}\text { "'The insole board is the surface upon which the foot } \\
\text { directly rests. The insole board provides a platform unon } \\
\text { which the foot can operate and separates the upper from } \\
\text { the lower"(McPoil Ir 1988) }\end{array}$ & $\begin{array}{l}\text {-"The insole of a shoe is also known as the sock liner" } \\
\text { and "To assess proper shooe fit using the insole, remove it } \\
\text { and compare it with the foot as a template."(Blazer, } \\
\text { Jamrog \& Schnack 2018) } \\
\text { "“Athletic shoewear will often have a sockliner, a piece } \\
\text { of material placed over the top of the insole barard. It } \\
\text { may be glued in position or removable."(McPoil Ir 1988) }\end{array}$ & 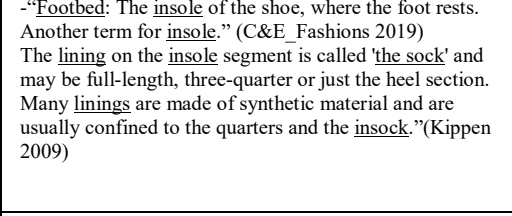 & $\begin{array}{l}\text { "Footbed or Insole is the foam padded mesh that your } \\
\text { foot stands on . May be removable or may be cemented } \\
\text { inn." And "Insole Board: a paper based board used to } \\
\text { provide structure inside a shoe. For example, a stiff } \\
\text { hiking boot will have a thick plastic lasting board. Also } \\
\text { called sockliner." (Motawi 2015) }\end{array}$ \\
\hline $\begin{array}{l}\text { shank/ } \\
\text { midfoot } \\
\text { shank/ } \\
\text { footbridge } \\
\text { / support } \\
\text { innsert }\end{array}$ & & 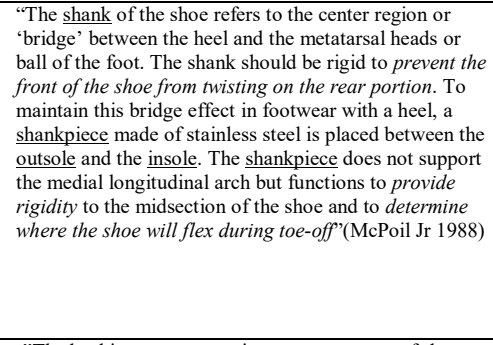 & $\begin{array}{l}\text { “....the presence of stability elements such as: } \\
\text { heel-counter, thermoplastic midfoot shank,...."(Ramsey } \\
\text { et al. 2019) }\end{array}$ & $\begin{array}{l}\text {-Shank: "A metal strip extending from the heel to the } \\
\text { ball of the foot to strengthen shoe and add support." } \\
\text { (C\&E Fashhions 2019) }\end{array}$ & 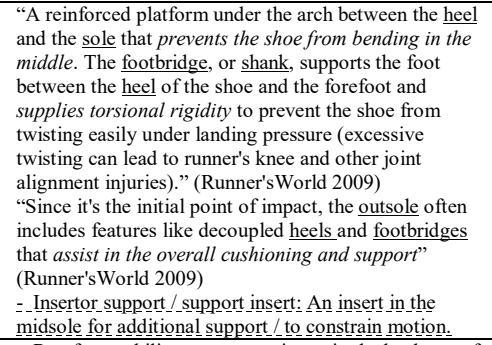 \\
\hline \multirow[t]{4}{*}{$\begin{array}{l}\text { Heel/ } \\
\text { rearfort } \\
\text { stabioilizerer }\end{array}$} & & $\begin{array}{l}\text {-"The heel is a component in numerous types of shoes } \\
\text { and can be o ovarious lengths depending on the specific } \\
\text { stylle." And "Men's heels are standardized in shape for } \\
\text { most shoe styles and have a heel height of about } 1 \text { inch. } \\
\text { Womene's heels come in numerous shapes and stslys to } \\
\text { complement different fashions of dress." (McPoil Jr } \\
\text { 1988) }\end{array}$ & & 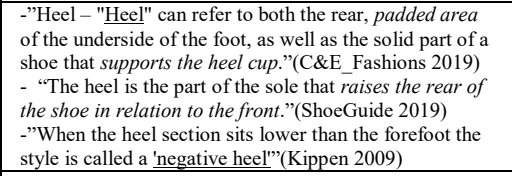 & $\begin{array}{l}\text { Rearfoot stabilizer:-a a support insert in the heel part of } \\
\text { the midsole, to stabilize the rearfoot. }\end{array}$ \\
\hline & top piece & & & $\begin{array}{l}\text { - The ground contact section of the heel is called the top } \\
\text { piece. (Kippen } 2009 \text { ) } \\
\text { "'The top piece is the actual part of the heel that comes } \\
\text { in to contact with the ground"(Muzquiz } 2017 \text { ) } \\
\text { "."The part of the hee lthat comes in contact with the } \\
\text { ground is known as the top piece."(ShoeGuide 2019) }\end{array}$ & \\
\hline & $\begin{array}{l}\text { heel seat/ } \\
\text { heel base }\end{array}$ & & & 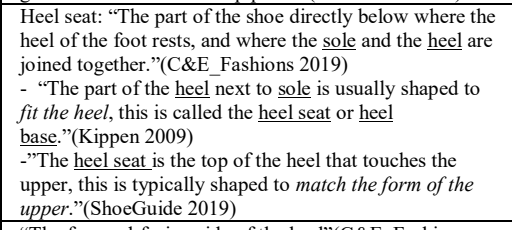 & \\
\hline & heel breast & & & $\begin{array}{l}\text { "The forward-facing side of the heel"'(C\&E_Fashions } \\
2019) \\
\text {-"The forward facing part of the heel, under the arch of } \\
\text { the sole"(ShoeGuide 2019) } \\
\text { "The heel breast describes front face of the } \\
\text { heel."(Kippen 2009) }\end{array}$ & \\
\hline $\begin{array}{l}\text { platform/ } \\
\text { front } \\
\text { platform/ } \\
\text { wedge }\end{array}$ & & 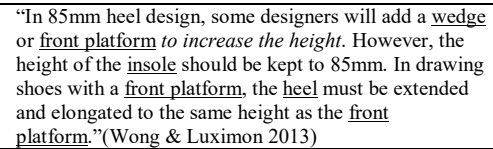 & & & \\
\hline
\end{tabular}




\begin{tabular}{|c|c|c|c|c|}
\hline 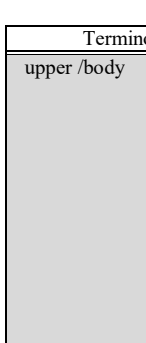 & 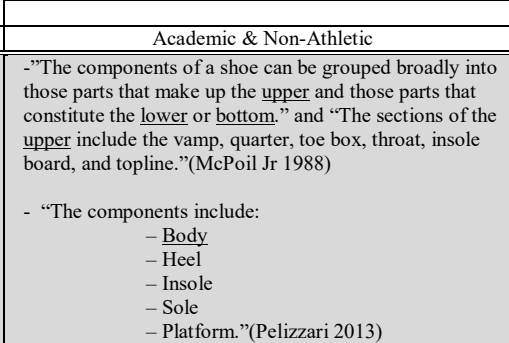 & 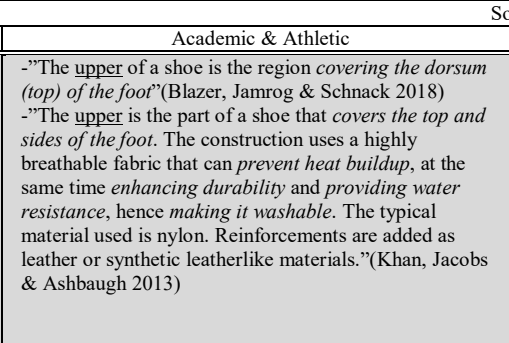 & 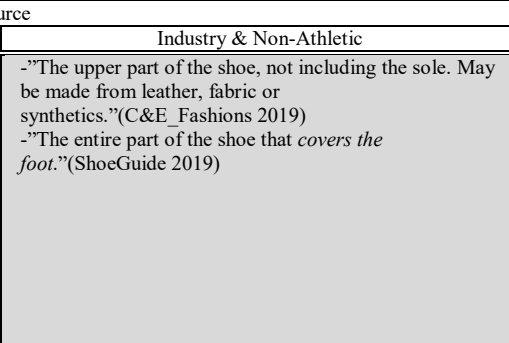 & 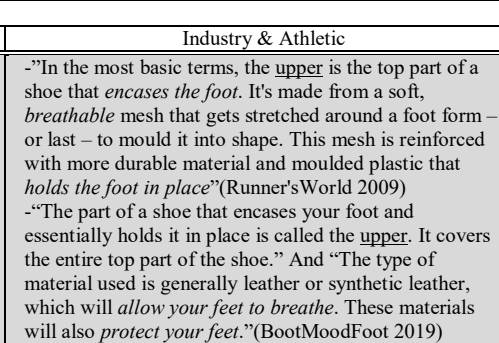 \\
\hline vamp & 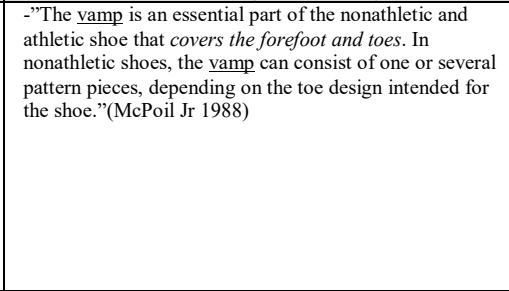 & 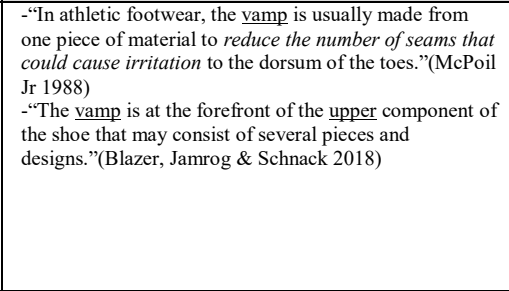 & 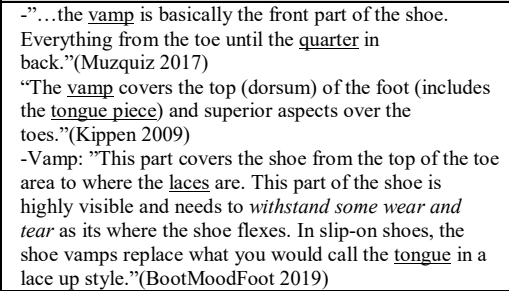 & 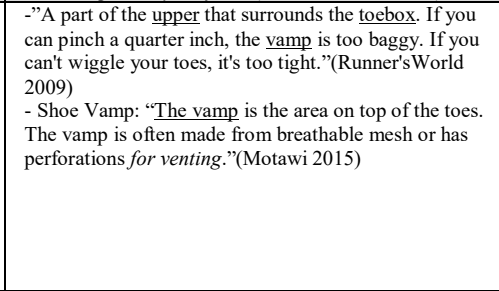 \\
\hline 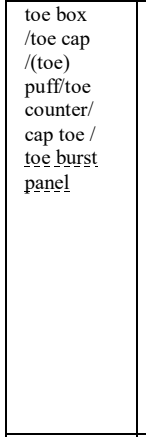 & 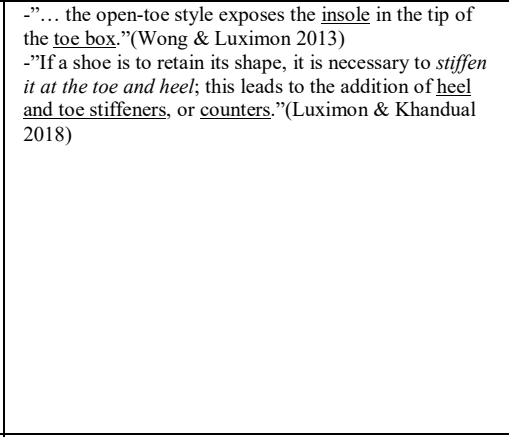 & 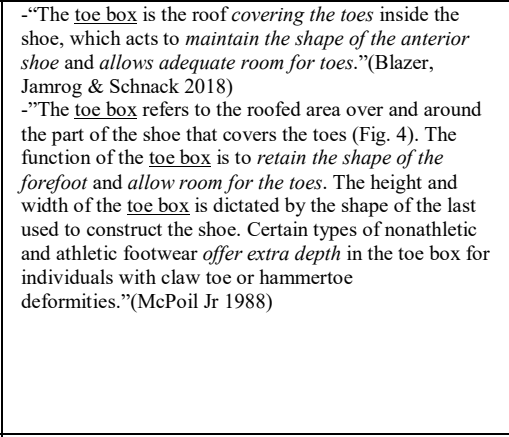 & 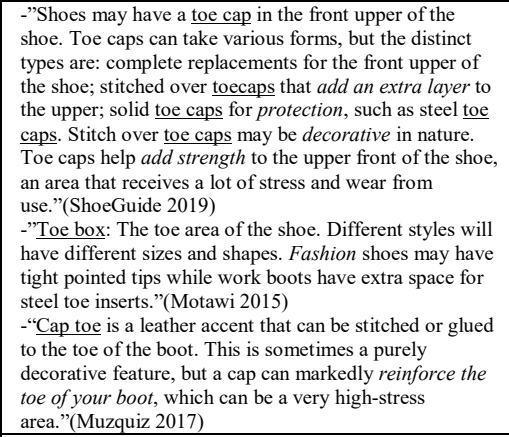 & 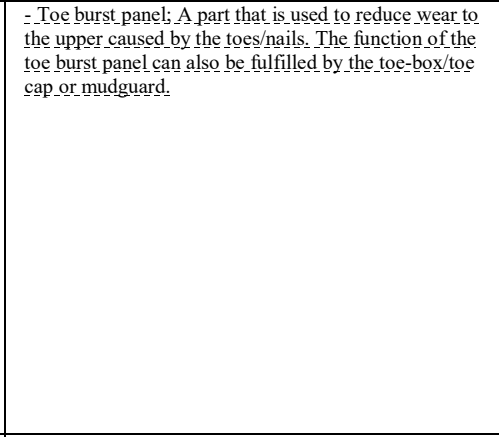 \\
\hline mudgatrar & & 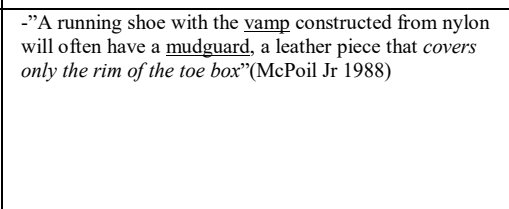 & 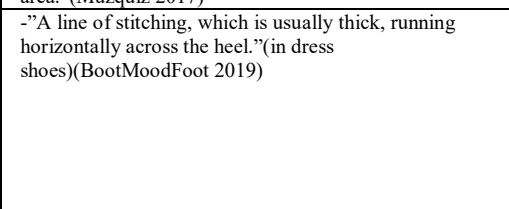 & 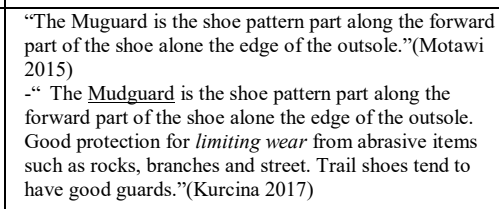 \\
\hline 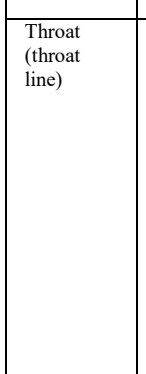 & 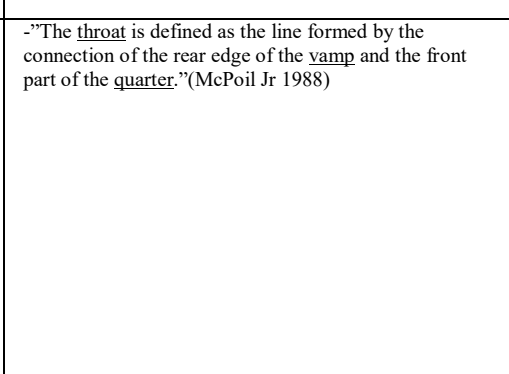 & 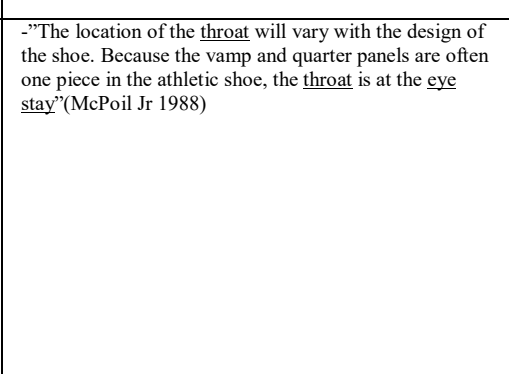 & 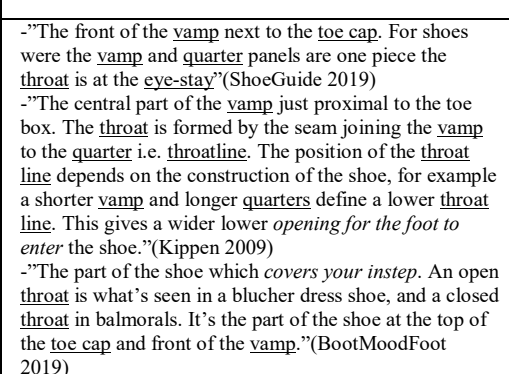 & 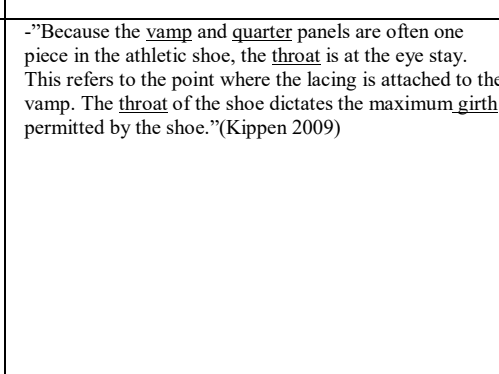 \\
\hline 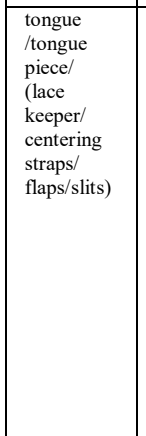 & & 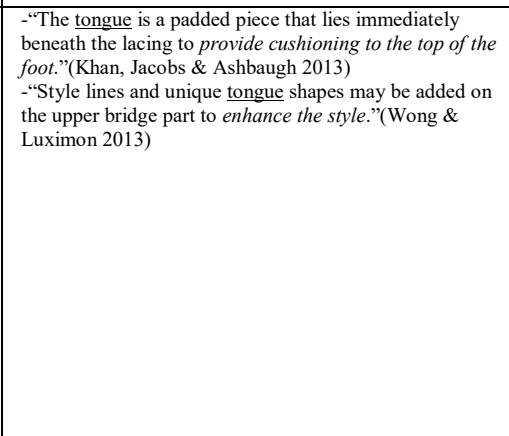 & 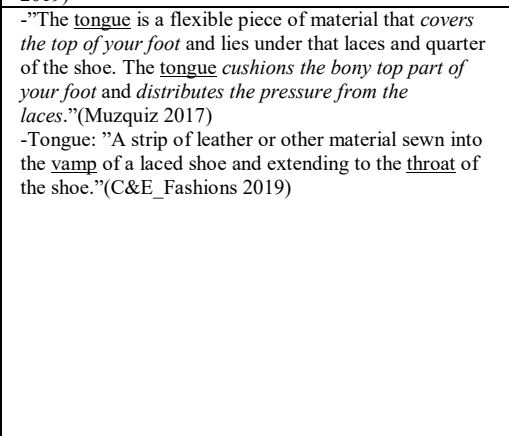 & 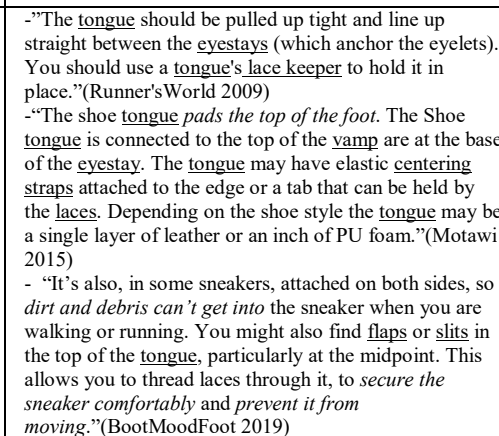 \\
\hline 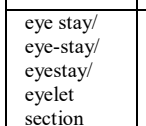 & & & 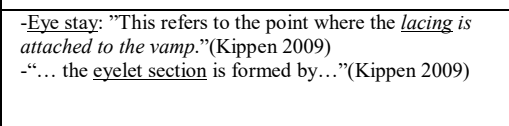 & 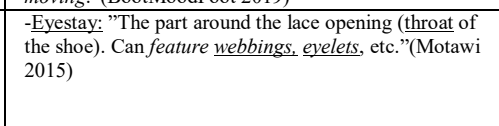 \\
\hline 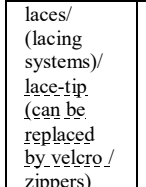 & & 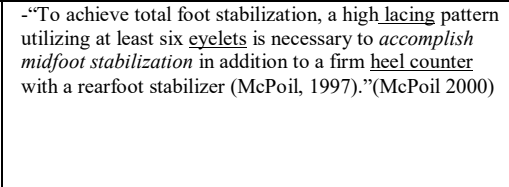 & 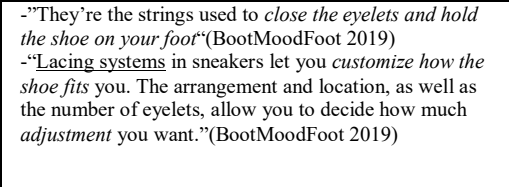 & 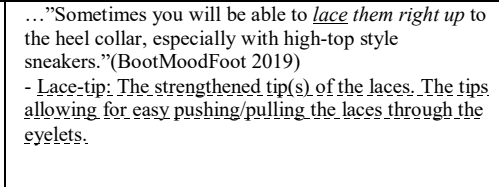 \\
\hline 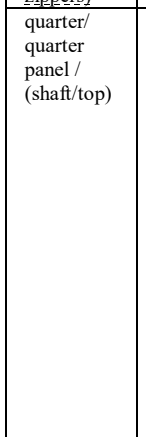 & 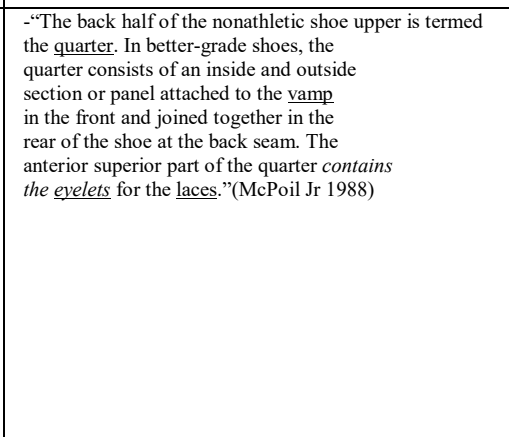 & 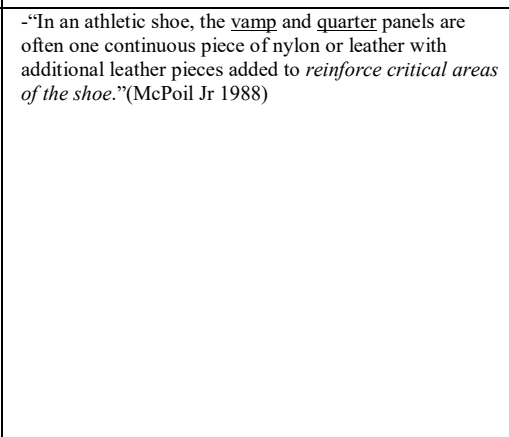 & 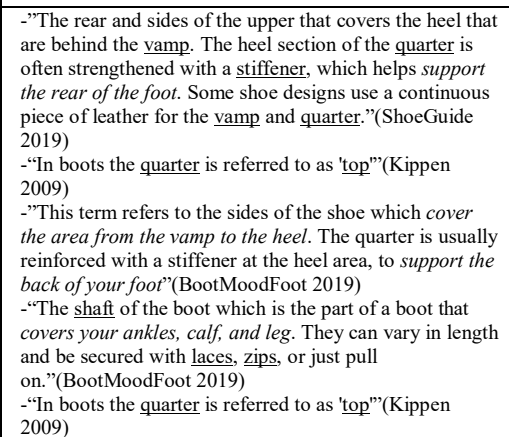 & $\begin{array}{l}\text { The } \\
\text { Thin }\end{array}$ \\
\hline 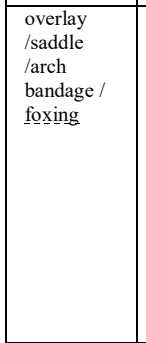 & & 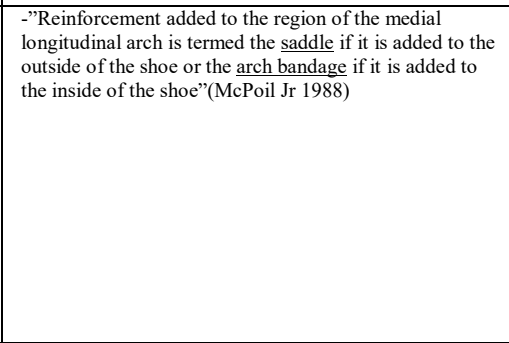 & 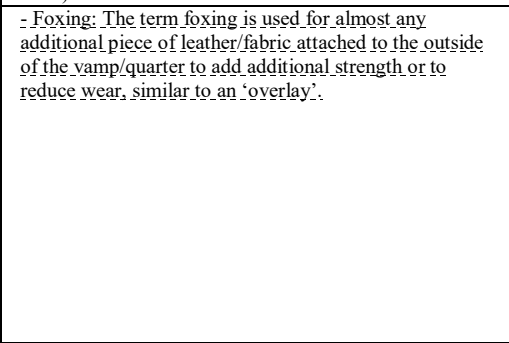 & 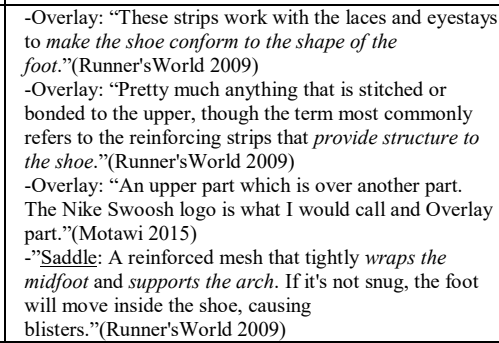 \\
\hline 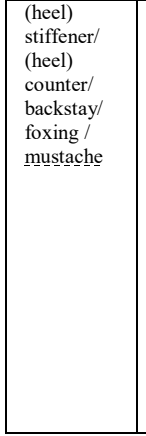 & 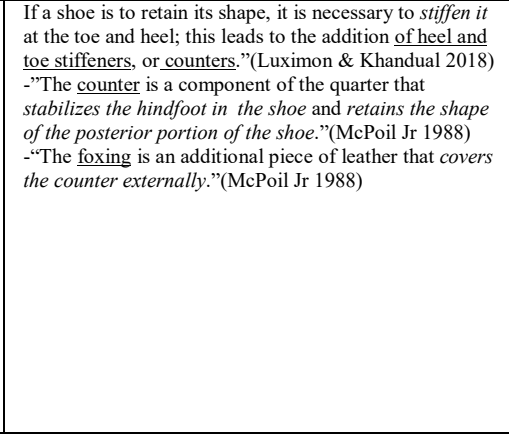 & 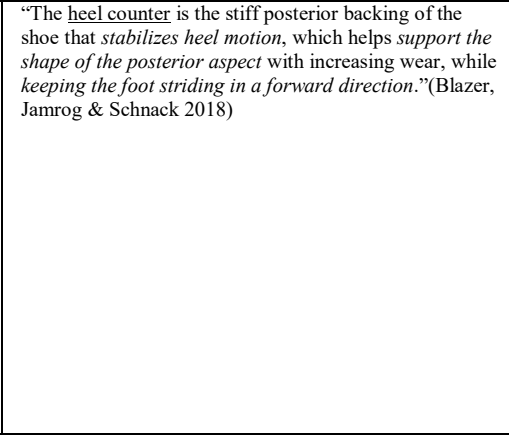 & 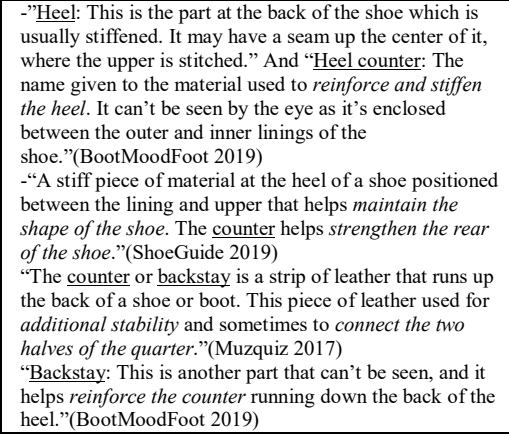 & 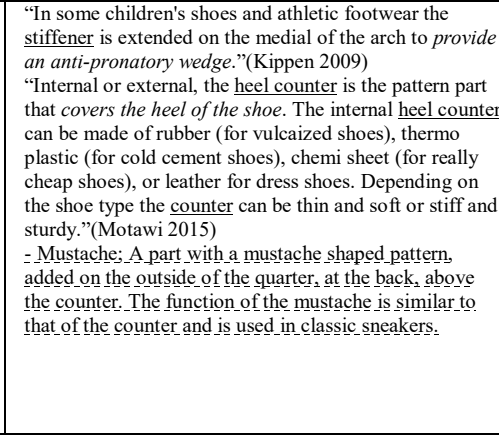 \\
\hline
\end{tabular}




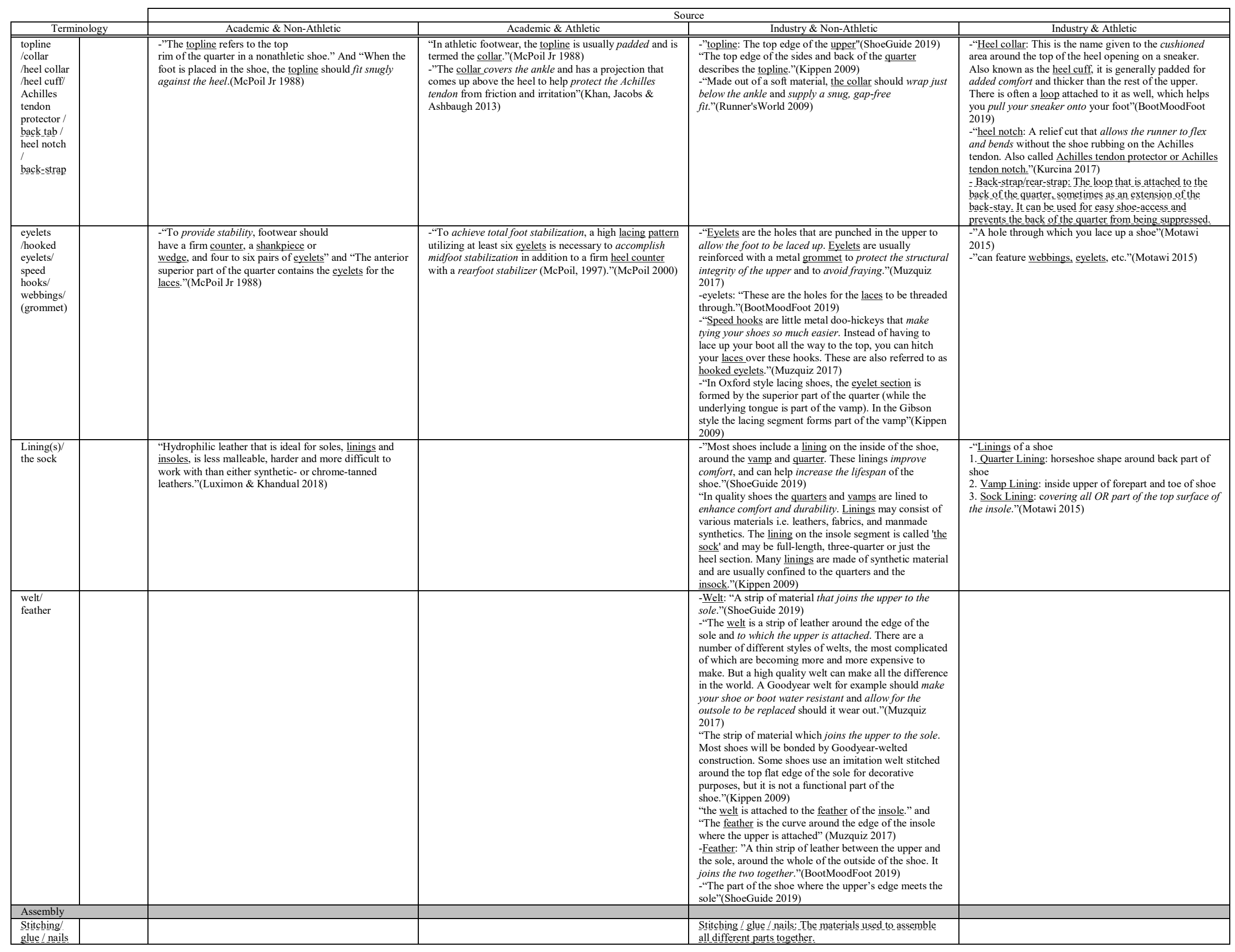

\section{References}

Blazer, MM, Jamrog, LB \& Schnack, LL 2018, 'Does the Shoe Fit? Considerations for Proper Shoe Fitting', Orthopaedic Nursing, vol. 37, no. 3, pp. 169-174.

BootMoodFoot 2019, What are the parts of a shoe and a sneaker? An anatomy of a shoe., viewed 07-29-2019, $<$ https://bootmoodfoot.com/partsanatomy-of-a-shoe/s.

C\&E_Fashions 2019, Glossary of Shoe Terms, viewed 07-25-2019, <https://www.candefashions.com>.

Davis, IS 2014, 'The Re-emergence of the Minimal Running Shoe', Journal of Orthopaedic \& Sports Physical Therapy, vol. 44, no. 10, pp. 775784.

Khan, MN, Jacobs, BC \& Ashbaugh, S 2013, 'Considerations in Footwear and Orthotics', Primary Care: Clinics in Office Practice, vol. 40, no. 4, 2013/12/01/, pp. 1001-1012.

Kippen, C 2009, The anatomy of the shoe, viewed 07-23-2019, < $\underline{\text { http://allaboutshoes-toeslayer.blogspot.com/2009/10/anatomy-of-shoe- }}$ according-to-mephoil.html $>$.

Kurcina, M 2017, Anatomy of a shoe, viewed 07-27-2019, <https://spotterup.com/anatomy-of-a-shoe/>.

Luximon, A \& Khandual, A 2018, '18 - Footwear', in J Williams (ed.) Waterproof and Water Repellent Textiles and Clothing, Woodhead Publishing, pp. 533-558.

McPoil Jr, TG 1988, 'Footwear', Physical therapy, vol. 68, no. 12, pp. 1857-1865.

McPoil, TG 2000, 'Athletic footwear: Design, performance and selection issues', Journal of Science and Medicine in Sport, vol. 3, no. 3 , 2000/09/01/, pp. 260-267.

Motawi, W 2015, Shoe Dictionary, viewed 07-25-2019, <https://sneakerfactory.net>.

Muzquiz, A 2017, Shoe Anatomy 101 - Vamp, Welt, Quarter and More, viewed 07-29-2019, < $<$ htps://www.heddels.com/2017/09/shoe-anatomy101-vamp-welt-quarter-and-more/>.

Pelizzari, O 2013, '6 - Shoe design development', in A Luximon (ed.) Handbook of Footwear Design and Manufacture, Woodhead Publishing, pp. 117-127.

Ramsey, CA, Lamb, P, Kaur, M, Baxter, GD \& Ribeiro, DC 2019, '“How are running shoes assessed? A systematic review of characteristics and measurement tools used to describe running footwear"', Journal of Sports Sciences, pp. 1-13.

Runner'sWorld 2009, Shoepaedia: Key Running Shoe Terms Explained, viewed 07-23-2019, <https://www.runnersworld.com/uk>.

ShoeGuide 2019, Anatomy of the Shoe, viewed 07-29-2019, <https://www.shoeguide.org/shoe anatomy/>.

Wong, WC \& Luximon, A 2013, '8 - Footwear drawing templates and shoe design', in A Luximon (ed.) Handbook of Footwear Design and Manufacture, Woodhead Publishing, pp. 150-174. 
APPENDIX B:

THE A3AO OF CONVENTIONAL FOOTWEAR 


\section{CONVENTIONAL FOOTWEAR}

(OVERVIEW)

FUNCTIONAL VIEW

FUNCTIONS OF CONVENTIONAL FOOTWEAR

Secure to foot (secure midfoot, secure heel, ...) Detach from the foot Protect foot/body (frictional forces, moisture,... Enclose foot (optional: ankles, calf and leg

Guide foot into shoe

Transmit force (foot to ground)

Regulate temperature (foot)

Display personality

Distribute pressure

Feel comfortable (to the skin) (shoe)

Limit wear (shoe)

Condition cleanliness (shoe)
Provide template (shoe-fittin

Adjust fit (shoe)

Maintain shape (shoe)

Support foot $(\operatorname{arch}, \ldots)$

Stabilize foot/body

Constrain motion

Reduce shocks

Increase height

Increase angle

imit torsion (shoe)

Control flexion / limit flexion zone (shoe)

Locate eyelets/webbings for lacing (shoe)

Guide laces (shoe)
Join parts (shoe)
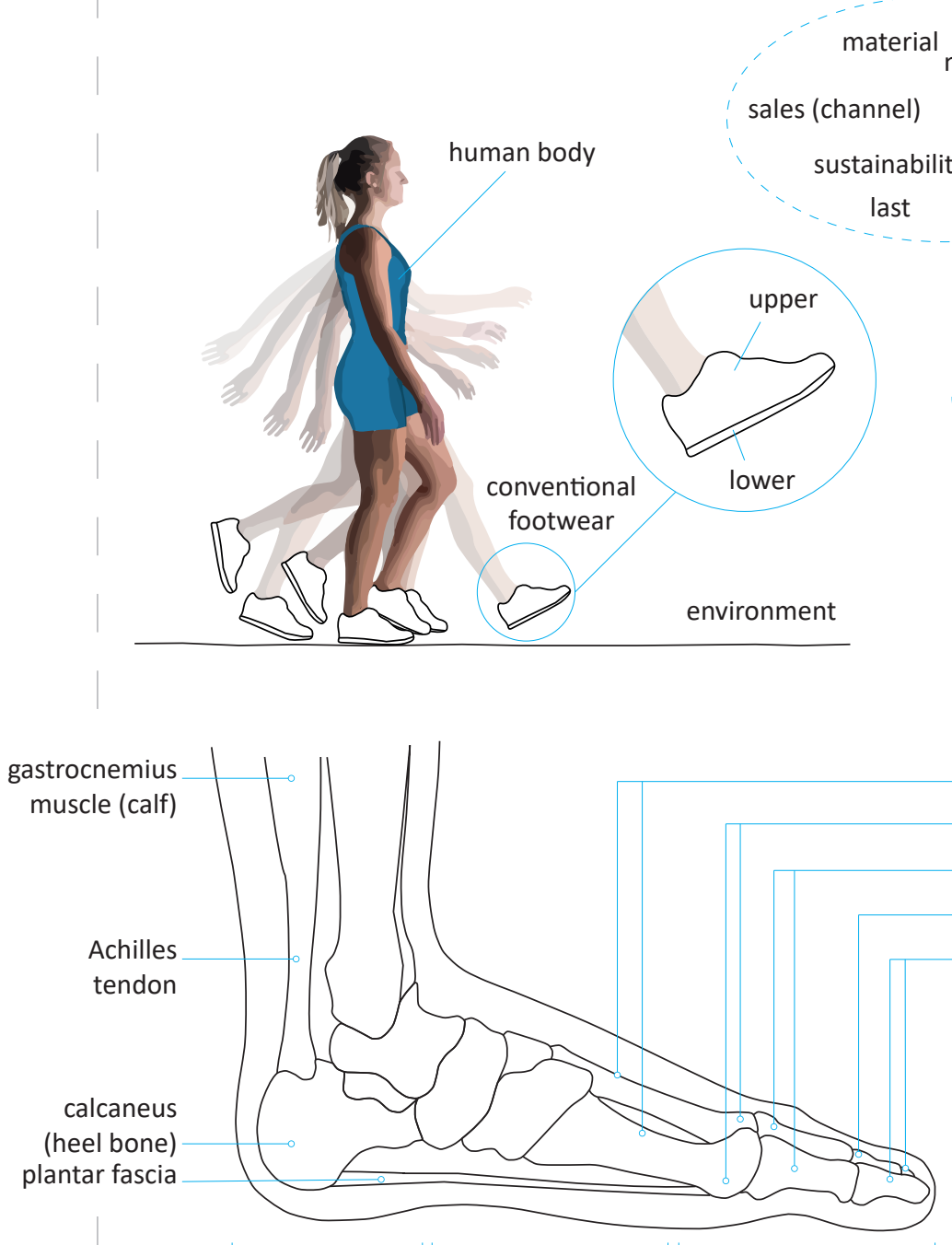

rear foot (heel)

mid foot

fore foo

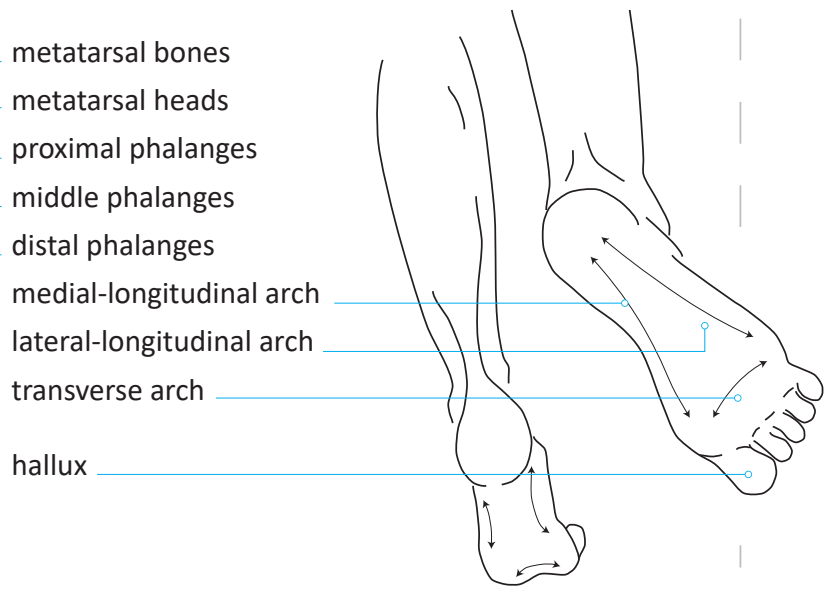

\section{CONSTRAINTS}

The development of conventional footwear is limited by the use of so-called 'shoe lasts', being solid models of the footwer the uperis moulde dround he last and attached to the low Afterwards, the last can be

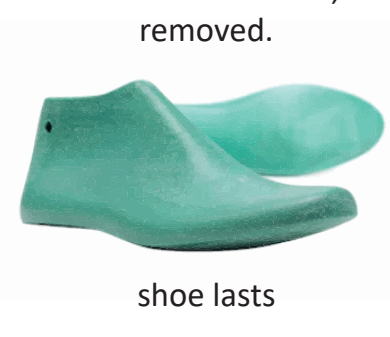

NON-ATHLETIC

MEN'S FOOTWEAR

\section{PHYSICAL VIEW}

ATHLETIC FOOTWEAR

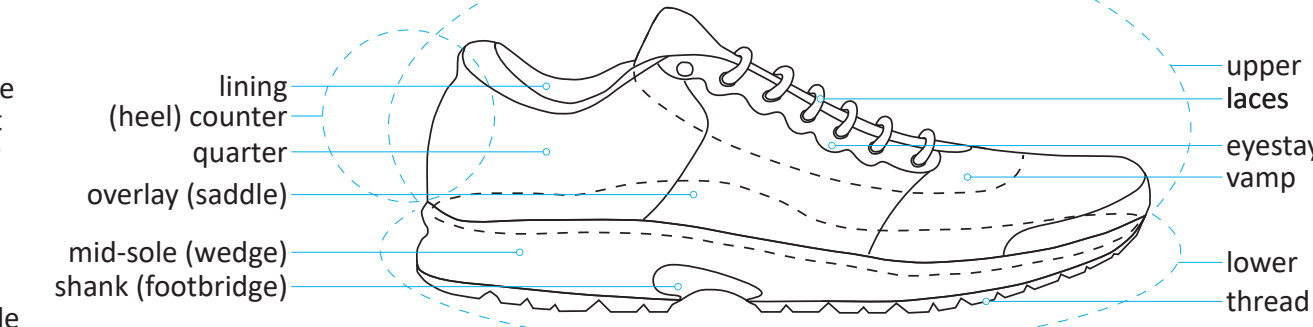

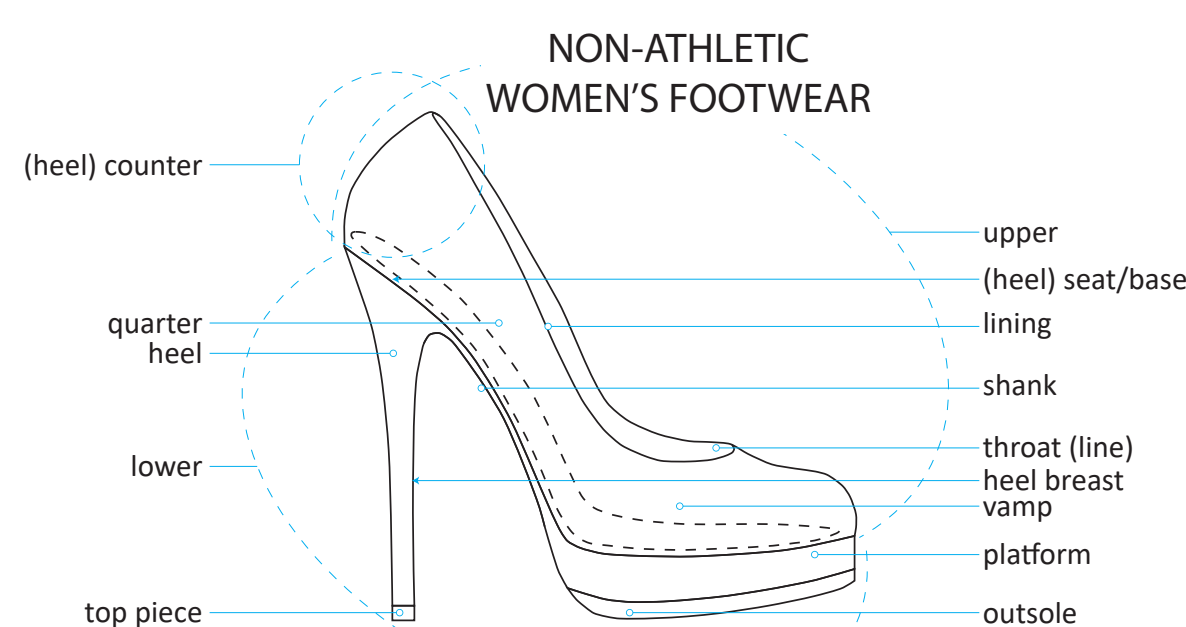

\section{QUANTIFICATION VIEW}

During the development of footwear, a suitable balance ould be found between:

Appearance
Durability Performance Healthfulness

shoe lasts
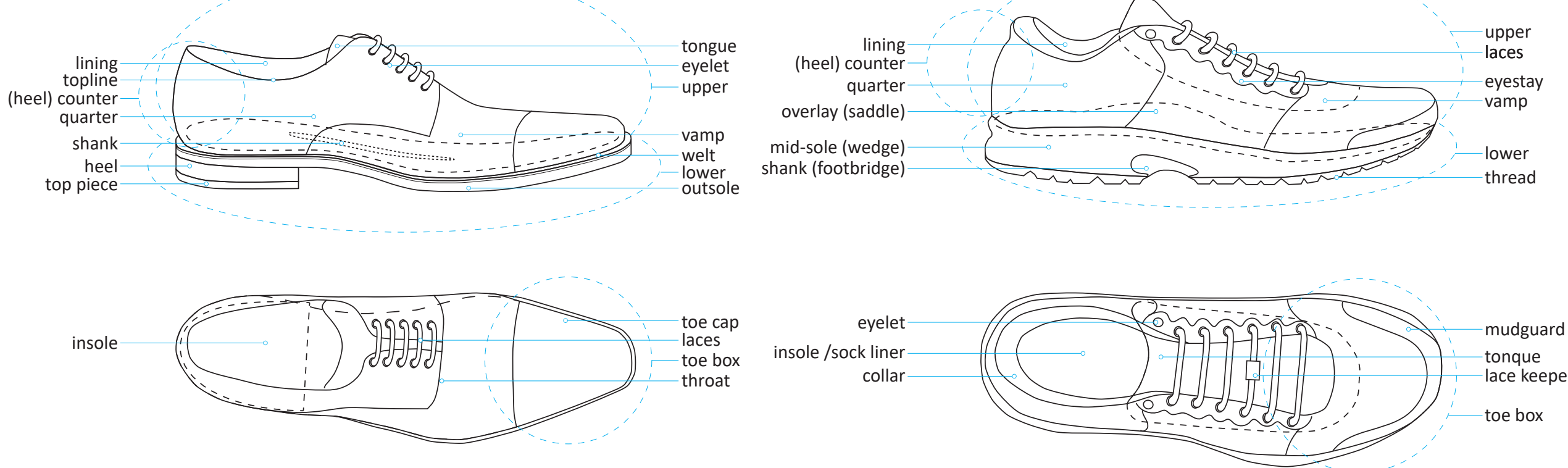

insole-

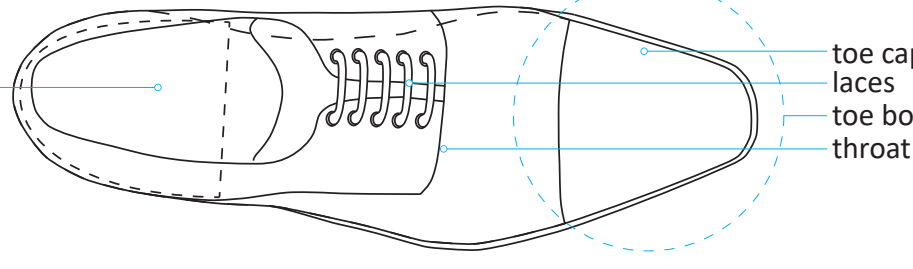




\section{INTRODUCTION}

The architecture of nowadays conventional footwear is the result of a long history of footwear design, manufacturing and marketing. In this long history, part of the argumentation behind the architecture has been lost, causing footwear developers to make decisions based on beliefs, habits and badly underpinned assumptions.

With new insights on the negative influence of most conventional footwear on human (foot) health in combination with the design freedom created by modern manufacturing techniques, the common dey na feedom created by modern 作 hand.

To allow footwear developers to consciously and intentionally deviate from the conventional architecture and work towards product evolutions, this A3 footwear developers conscious about the design decisions they make in relation to 'the standard' (functions, key-parameters, physical appearance), they can purposefully decide to deviate from this while overlooking the conseguences, independent of the type of evolution they strive for

\section{TOP-LEVEL VIEW}

In the Western world, footwear is so commonly used that it has become inherently part of our being in the world. It is via footwear that users are in almost constant contact with different types of environments. While serving as an extension of the human body, the earliest footwear has had both a protective and a symbolic function. Nowadays, footwear developers have succeeded to include many more functions, partly - or sometimes entirely taking over functions from the human body (see functional view).

In its basis, conventional footwear consists of two major sub-assemblies: the so-called 'lower' and 'upper'. During manufacturing, the upper is moulded around a shoe last (a solid model of the foot) and attached to the lower; the two become inseparable.

The upper has an opening that moved nd the foot to enter during use. footwear to the foot The upper covers the sides and top of the foot; the lower is in contact with the foot.

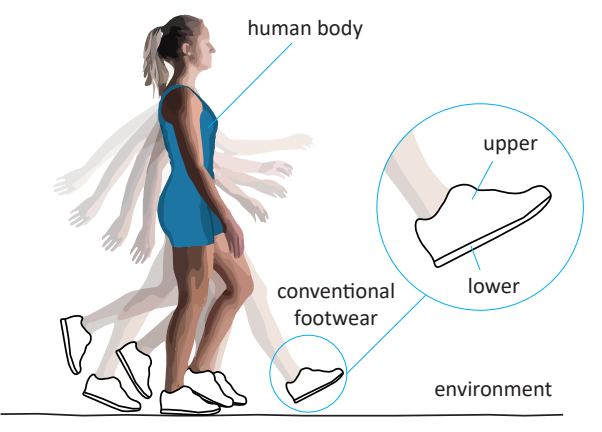

METHODS

The views in this A3AO were created by using the following method (see also [2])

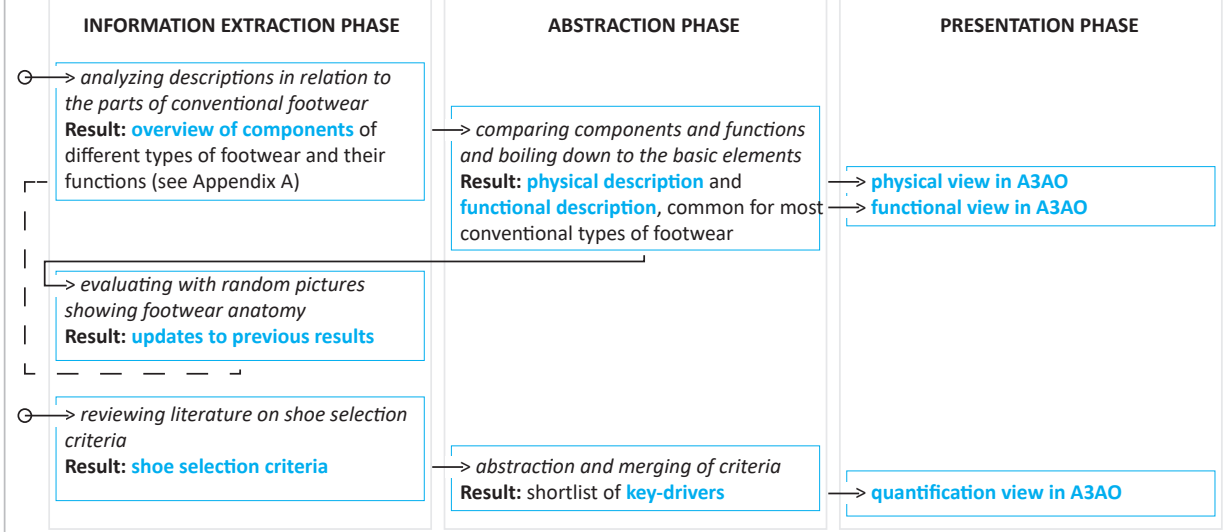

\section{FUNCTIONAL VIEW}

The functional view on the other side of this sheet shows a list of the functions that can be fulfilled by conventional footwear. Information for this functional view was collected by analyzing descriptions - that are used by academics as well as in industry - in relation to the parts of non-athletic (men's and women's) footwear as well as athletic footwear. The analysis (milted in an overview of the components of different types of footwear as well as the functions thereof (see Appendix A).

The overview was checked by comparing with a total number of 18 pictures of footwear anatomy from which the terminology was compared and based on which a few additions were made.

From the updated overview the function descriptions were rephrased by using terms from the 'Functional basis reconciled function set' defined by the National Institute of Standards and Technology, NIST [1]. This was done with the aim to boil down to a limited and uncluttered set of different functions per part, that adheres to accepted terminology (see Table 1 in [2]). Eventually a general list of possible footwear functions was derived by The list is represented in the FUNCTIONAL VIEW on the other side of this sheet

\section{PHYSICAL VIEW}

The terminology that is listed in Appendix A was eventually used to create the physical description of conventional (non-athletic and athletic) footwear presented the physical view. When multiple terms were mentioned in the same row of the table in Appendix A, a general term was selected to be used for the physical description.

An additional description of a non-athletic women's pump was added to show the large overlap in terminology with non-athletic men's footwear while having a complete different appearance, the represented shoe style ('pump') merely consists of less parts and has is specific for this type of shoe.

It should be noted that the physical view (see PHYSICAL VIEW on the other side of this sheet) merely shows three different types of shoes; many more different types of shoes exist, with different appearances. The terminology of parts, however, largely remains the same for all these different types. For a more complete list of similar terms for parts, the use of Appendix A should be consulted.

\section{KEY-PARAMETERS \& REQUIREMENTS}

Footwear users can have many different criteria for selecting a specific (type of) shoe. Review of literature on shoe selection criteria lead to a list of (sometimes overlapping) criteria that could eventually be summarised into a
list of 6 main criteria. For designers, these

iteria are the key-drivers that should be reckoned during design. A suitable balance should be found between:

$$
\begin{gathered}
\text { PRICE } \\
\text { COMFORT } \\
\text { APPEARANCE } \\
\text { DURABILITY } \\
\text { PERFORMANC } \\
\text { HEALTHFULNESS }
\end{gathered}
$$

Together these criteria establish the quantification view.

\section{KNOWN ISSUES}

Footwear developers have - for a long time - seen the foot as a fragile body part that needs to be protected, supported and packed. Today, more and more research illustrates the health benefits that are gained by allowing our feet to function in their most natural way. The key-parameter 'healthfulness' seems to become increasingly relevant, and as a result, some of the functions that are currently fultiled by footwear aight, soed to be canefuly

* Due to technology advances and modern manufacturing techniques, new possibilities come within range that can allow footwear developers to reconsider:

\section{shoe customisation possibilities,}

the of materials,

.

the distinction between upper \& lower,

ROADMAP

In future footwear development, three different scenarios can already be foreseen:

\section{Short term}

In a first scenario, footwear still has a conventional product architecture and is being produced by using conventional manufacturing techniques and materials. Thends (e in foot health), leading to changes in the functions of foower.

\section{Mid term}

In a second scenario, footwear with a conventional product architecture can be produced by using modern and unconventional manufacturing techniques or e. e. allowing for affordable (mass) customisation. Footwear users are able to customise their footwear based on price / comfort / appearance / durability / performance and healthfulness demands.

Long term

In a third and most futuristic scenario the second scenario is supplemented with the possibility to create footwear that has a completely different product architecture.

\section{REFERENCES}

Experts

Winnie Dankers (w.dankers@utwente.nl)

Maarten Bonnema (g.m.bonnema@utwente.nl)

\section{Appendices}

Appendix A: Terminology related to the functional parts of footwear

\section{Literature}

[1] Hirtz, J., et al., A functional basis for engineering design: reconcilin and evolving previous efforts. Research in engineering Design, 2002. 13(2): p. 65-82

2] Dankers, W.; Bonnema, G.M. Reverse Architecting Conventional
footwear, T.B.P. 